\title{
Fen Eğitiminde Kavram Öğretimi Konulu Araştırmaların Sistematik Derleme Yöntemiyle İncelenmesi
}

Menşure Alkış Küçükaydın ${ }^{1}$

Öz

Anahtar Sözcükler

Bu çalışmanın amacı, son 15 yıllık dönemde fen eğitiminde kavram öğretimi konusunda yürütülen araştırmaların yönünün belirlenmesi ve ortaya çıkan sonuçlara dayanarak kavram öğretimi konusundaki gelişmelerin tanıtılmasını sağlamaktır. Çalışmada 2005-2020 yılları arasında Türkiye'de fen eğitiminde kavram öğretimi konulu 42 makale ile 15 lisansüstü tez olmak üzere toplam 57 araștırma, incelemeye alınmıştır. Araştırmalar; yayın yıllı, yayın türü, amaç, yöntem/desen, örneklem, veri toplama araçları, fende kavram öğretiminde tercih edilen yöntem/teknik, veri analiz yöntemi, incelenen konu, sonuç ve önerì temalarına uygun olarak incelenmiş̧tir. İncelemeler; kavram öğretim tekniklerinin neredeyse hepsiyle ilgili deneysel çalışmaların yürütülmüş olduğunu, bu nedenle de araştırma amaçlarının çeşitlendiğini, araștırmaların çoğunlukla ortaokul öğrencileriyle yürütüldüğünü, genellikle 2-3 aşamalı başarı ya da kavram testlerinin kullanıldığını, kavram haritalarına oldukça geniş bir yer verildiğini ve kavram yanılgıları üzerine yoğunlaşıldığını göstermiștir. Bu sonuçlara dayanarak kavram öğretiminin STEM uygulamaları ile bütünleştirilmesi, ilkokul yıllarından itibaren kavram öğretimi konulu tasarım çalışmalarının yapılması, bilgisayar ya da web tabanlı uygulama tekniklerinin bilişüstü becerilere ve 21. yüzyıl becerilerine olan etkilerinin incelenmesi konusunda önerilerde bulunulmuştur.

Fen eğitimi

Kavram öğretimi Sistematik derleme

Makale Hakkında

Gönderim Tarihi

01 Haziran 2020

Kabul Tarihi

01 Aralık 2020

Makale Türï

Araştırma Makalesi

DOI: $10.12984 /$ egeefd. 746326

\section{Examination of Studies on Concept Teaching in Science Education: A Systematic Review of Literature}

Abstract

Keywords

The aim of this study is to determine the direction of the research studies carried out in the concept of the teaching in science education in the last 15 years and to introduce the developments in concept teaching based on the results. Total of 57 research studies on the concept teaching in science education in Turkey (including 42 articles and 15 dissertations) published between years of 2005-2020 were reviewed. These research studies were examined via themes as the year of publication, type of publication, purpose, method/ pattern, sampling level, data collection tools, preferred method/ technique in science education, data analysis method, subject examined, results and suggestions. The results revealed that the experimental study on almost all of the concept teaching techniques has been carried out, therefore, it has shown that the study objectives are diversified, mostly studies with middle school students are conducted, usually, two/three stages of success or concept tests are used, concept maps are widely utilized and studies on misconceptions are common. Based on these results, suggestions were made to integrate concept teaching with STEM applications, to conduct design studies on concept teaching from primary school years, and to examine the effects of computer or web-based application techniques on metacognitive skills and 21st century skills.

Science education

Concept teaching

Systematic review

Article Info

Received

June 01, 2020

Accepted

December 01, 2020

Article Type

Research Paper

Atıf: Alkış Küçükaydın, M. (2020). Fen eğitiminde kavram öğretimi konulu araştırmaların sistematik derleme yöntemiyle incelenmesi. Ege Ĕgitim Dergisi, 21(2), 36-56. doi: 10.12984/egeefd.746326

\footnotetext{
1 Necmettin Erbakan Üniversitesi, Ereğli Eğitim Fakültesi, Temel Eğitim Bölümü, Sınıf Eğitimi Anabilim Dalı, Türkiye, mensurealkis@hotmail.com
} 


\section{Extended Abstract}

\section{Introduction}

In the constructivist approach, the importance of items such as helping students experience discovery, experimenting, and material usage are frequently mentioned. In addition, in learning, it is seen that the teachers are in a guiding position and it is prompt to use different methods and strategies because of the principle of relativity to the individuals. The related literature indicates that teachers generally use two types of methods for teaching concepts. The first one is the traditional approach, in which the definitions of the concepts are given by the teachers and mentioned or unmentioned examples are discovered by students. As for the second method based on the constructivist approach, students figure out modified or unmodified features by looking at the examples that are included or unenclosed in the relevant concept and at the same time structure the information on their own. For this reason, based on the constructivist approach, it is recommended to use appropriate methods and techniques for students for concept teaching. Being frequently used tools for teaching concepts, these related techniques are also used to provide conceptual change. From that change, it is determined to be beneficial to do scientific research to identify in what way there are changes for concept teaching in science in Turkey for the last 15 -year period and identify new concept teaching methods and techniques that emerged in that period, fix the shortcomings and introduce new approaches. Therefore, in this study, it is aimed to investigate the research studies published between the years 2005-2020 on teaching concepts in science education in Turkey with the systematic review methodology.

\section{Method}

In this study, systematic review methodology was used. In this study, first of all, national databases were examined to analyze the studies on concept teaching in science education in Turkey between the years 2005-2020. The keywords used in this study were; the concepts in science education, concept teaching, teaching concept in science education. In relevant scans, attained books, research, and lecture reports, as well as summaries or full-text papers were not included in the study. This research period covered the dates starting from December 2019 to February 2020. Reporting the findings of the survey into Excel was carried out between February and March 2020. For this reason, the studies were published after March 2020 were excluded. Expert opinion was consulted in March and the findings of the study was written in April 2020. The studies gathered at the end of the research were recorded as full text. Each of these studies was coded in Excel under a certain parameter. These parameters are; publication year, type of publication, purpose, method / pattern, sampling level, data collection tool, concept teaching technique / method used in science, data analysis method, examined subject, result, and suggestion. To ensure the reliability of the study an expert's opinion was consulted who completed her Ph.D. in science education. Also, the researcher explained each step of the systematic review process in detail to ensure the validity of the study.

\section{Findings}

In Turkey, there were many publications about teaching concepts in science in 2011. The least publication was published in 2005 and 2019. However, there wasn't any study on concept teaching in science in 2015. A total of 22 research studies were related to misconceptions, 37 of researches were about examining the effect of concept teaching techniques on different variables, four of them were related to introducing, comparing and using the concept teaching methods/techniques in science education, two of them were about sample activity design. It was observed that student/teacher's opinion was consulted in three and sample activity design was carried out in two related studies. Mostly quantitative methods were used in these research studies. Most of them were conducted at the secondary level, a maximum of two/three stages of success or concept tests were used, most of the time concept maps were used and quantitative data analysis methods were used as data analysis method. Due to the excessive use of quantitative research methods in studies, quantitative data analysis methods were high in number. Of the related research studies, 21 in the field of biology, 16 in physics, 15 in chemistry, two in environment, and three in general subjects. In three of the studies, the subject was not clearly stated. 16 of the results obtained from the research were related to misconceptions, 46 were related to the effect of the concept teaching techniques used on other variables, and 10 were related to descriptive results. In one research, the result was not clearly included. In addition, it was found that 27 suggestions were presented for teachers and the Ministry of National Education, four suggestions were presented for teacher educators and 29 suggestions were presented for researchers.

\section{Discussion and Conclusion}

Generally, one or more concept teaching techniques were selected in the research studies and the effectiveness of this technique was examined. Designing exemplary activities that include all teaching techniques requires certain specialist knowledge and effort. Therefore, the low number of design-based studies may be related to this situation. 
In addition, it is remarkable that the researches carried out on misconceptions are quite high. Based on this systematic review study, the following suggestions are presented:

1. As it is known, in 2018, the science education curriculum was renewed and a STEM integrated program was initiated. In addition, concept teaching is always important in science and will continue to maintain its place. Therefore, new research should be conducted in which concept teaching will be integrated with STEM applications.

2. Design-based studies are needed for concept teaching. It is important for design-based teaching to be carried out in the first years in terms of science education. For this reason, it is recommended to carry out design studies on concept teaching from elementary school years.

3. In the related study, it was observed that the studies carried out with mixed methods are limited only to doctoral dissertations. Based on this, it is recommended that the process of concept formation and change in teachers and students are investigated thoroughly by providing methodological diversity. In addition, meta-analysis studies can be conducted to examine the effectiveness levels of concept teaching methods and techniques.

4. In today's world, where the use of technology has become widespread, teaching concepts in science education also needs to be integrated with technology. For this reason, computer or web-based concept maps, concept cartoons, mind maps, analogy, etc. effects of techniques on metacognitive skills or $21 \mathrm{st}$ century skills should be examined. 


\section{Giriş}

Ekonomik İşbirliği ve Kalkınma Örgütü (Organization for Economic Co-operation and Development [OECD], 2019) tarafından düzenlenen ve Türkiye'nin de katılmış olduğu Uluslararası Öğrenci Değerlendirme Programı (Programme for International Student Assessment-PISA), 2018 fen bilimleri değerlendirme anketi sonuçlarına göre Türkiye'de öğrencilerin sadece \% 2'si fende en yüksek performansı gösterirken, bu oran OECD ortalamasında \% 7'dir. Ortaya çıkan bu durum her ne kadar bir önceki rapora göre iyileşme olduğunu gösterse de istenilen noktaya henüz ulaşılamamıştır. Bu sonuçlar öğrencilerin, bilimin günlük yaşamla ilişkilendirilmesi noktasında sıkıntıları olduğuna işaret etmektedir. Fen eğitimi açısından değerlendirildiğinde, öğrencilerin günlük yaşamla bilimi ilişkilendirememe sıkıntılarının ele alınarak çözüme kavuşturulması, önemli bir meseledir. Ancak çözülmek istenen bu meselenin yeni olmadığı da bilinmektedir. 20. yüzyılın başlarında okullarda öğretilen fen bilgisinin, günlük yaşamla ilişkilendirilmesi gerektiğine değinen çalışmalar, fen içeriği ile günlük yaşam bağlamına işaret etmektedir (Mead, 1909). Dolayısıyla bu sorunun çözümü için fen eğitimi alanyazınında öğrencilerin ilgisini çekmeyi başarabilecek farklı etmenler üzerinde durulmuştur. Öğrencilerin yaşı, cinsiyeti, sosyo-ekonomik düzeyleri gibi değişkenler dışında fen eğitiminde kavram öğretimi konusunda tercih edilen yöntem ve tekniklerin etkililiği genel olarak bu çalışmaların ilgi odağı olmuştur (Bryne ve Johnstone, 1988; Frailich, Kesner ve Hofstein, 2007; Häussler ve Hoffman, 2000). Söz konusu çalışmaların sonuçları ise öğrencilerin pozitif sınıf iklimini tetikleyen ve bilgilerini yapılandırmalarına izin veren yöntem ve tekniklerin, fen öğrenimleri üzerinde olumlu etkileri olduğunu göstermektedir. Dolayısıyla öğretmenlerin fen sınıflarında olumlu duyguları destekleyen öğretim yöntemlerini seçmelerine yardımcı olunması gerekmektedir.

Türkiye'de 2005 yılında benimsenen yapılandırmacı yaklaşım ile fen programının sadece temel felsefesinde değil öğrenme ve öğretme etkinliklerinde de bu anlayışın esas alındığı belirtilmiştir (Milli Eğitim Bakanlığı [MEB], 2005). Öğretmenlerin, öğrencileri için fen öğrenmeye elverişli strateji kullanmalarının gerekliliği üzerinde durulmuştur. Temelde yapılandırmacı yaklaşımda, bireylerin fen öğrenmeleri için onlara keşif hissini yaşatma, deneyler yaptırma ve materyal kullanımı gibi ögelerin önemine sıklıkla değinilmiştir (Eggen ve Kauchak, 2004). Ayrıca öğrenmede, öğretmenlerin rehber konumunda olduğu ve öğretimde bireye görelik ilkesi gereği farklı yöntem ve stratejilerin kullanımının önü açılmıştır. Bu farklı stratejiler, kavram öğretimine yeni bir bakışın kazandırılmasına zemin hazırlamıştır. Bu noktada ilgili alanyazın, öğretmenlerin kavram öğretiminde genellikle iki yönteme başvurduklarını işaret etmektedir. Bunlardan ilki geleneksel yaklaşım olup kavramların tanımları öğretmenler tarafindan verilmekte, kavrama dâhil edilen ve edilmeyen örnekler öğrenciler tarafindan bulunmaktadır (Coştu, Karataş ve Ayas, 2003). İkinci yaklaşımda ise yapılandırmacılığa dayalı olarak öğrencilerin ilgili kavrama dâhil edilen ve edilmeyen örneklerinden yola çıkılarak kavramları niteleyen ve nitelemeyen özelliklere ulaşılması ve bu esnada öğrencilerin bilgiyi zihinlerinde yapılandırmaları söz konusudur (Martin, 2009). Bilginin yeniden yapılandırılması ve kavram öğretiminin gerçekleşmesi açısından yapılandırmacı anlayışın sunduğu yöntem ve tekniklerin kullanımı, bu noktada öğrenci merkezli öğrenmeyi de desteklemektedir. İnel, Balım ve Evrekli'nin (2009) 7. sınıf öğrencileriyle 7E modelini temel alarak kavram karikatürünü kullandıkları çalışmada, öğrencilerin \%70'i dersten zevk aldığını belirtmiştir. Aynı çalışmada öğrencilerin \%50'si, kavram karikatürlerinin derslerinde yararlı olduğunu bildirmiş, bu şekilde yapılan öğretimin sonunda fen ile günlük yaşam arasında daha rahat ilişki kurduklarını ifade etmişlerdir. Benzer şekilde Özatlı ve Bahar'ın (2010) lise öğrencilerinin boşaltım sistemi konusundaki bilişsel yapılarını kavram haritaları, kelime ilişkilendirme testleri, yapılandırılmış grid ve V-diyagramları kullanarak ortaya çıkarmayı amaçladıkları çalışmada, bu tekniklerle yapılan öğretimin öğrenci başarısını artırdığı görülmüştür. Bununla beraber öğrencilerin ilgili tekniklere yönelik görüşlerinin olumlu olduğu belirlenmiş ve kavram bilgisine ilişkin bilişsel yapıları ortaya çıkarılabilmiştir. Dolayısıyla öğrencilere kavram öğretimi konusunda sunulan kavram haritası ve kavram karikatürü gibi tekniklerin, öğrenciler üzerinde sadece akademik başarı açısından değil, öğrencilerin derse yönelik ilgilerini de artırmaya katkı sağladığı görülmektedir.

Hong ve Diamond (2012), çocukların doğal dünya hakkındaki bilgilerini artırmalarına yardımcı olmak için onlara fen kavramlarının doğru ve yerinde öğretilmesi gerektĭgini söylerler. Olson (2008) ise fen öğretiminin sadece formüllere indirgenmesi ve bu öğretimde değerlendirmelerin kâğıt-kalem testleri kullanılarak yapılması nedeniyle öğrencilerin fenle ilgili temel kavramları öğrenmede zorluk çektiklerini belirtmiştir. Dolayısıyla fen eğitiminde kavram öğretimi meselesi, inşâ edilecek bir binanın temeli olarak düşünülmelidir. Osborne ve Wittrock (1983) kavram geliştirmenin, yeni kavramlarla eski kavramların etkileşime girmesi sonucu meydana geldiğini ifade etmişlerdir. Burada bahsedilen kavram etkileşimi ise bireyin kavramlarla ilgili ön bilgisinde, kavram öğretimi sonucunda meydana gelen değişimdir. Bu değişim, Osborne ve Wittrock tarafından kavramsal değişim olarak ifade edilmiştir. Kavramsal değişim ise kavram yanılgılarının giderilmesinde kullanılan bir stratejidir.

Fen eğitiminde oldukça önemli bir yeri olan kavramlar (Ormrod, 2006), pek çok kez doğal yollarla veya dış kaynaklı sebepler yüzünden değişime uğrayarak kavram yanılgılarına dönüşmektedir (Hand ve Treagust, 1991; Karataş, Köse ve Coştu, 2003). Kavram yanılgılarının alanyazında farklı ifade şekilleri olmakla birlikte Kaltakçı Gürel, Eryılmaz ve McDremott (2015) bu ifadeyi, öğrencilerin sahip olduğu fikirler ile güncel bilimsel teoriler 
arasındaki farklılık olarak tanımlamışlardır. Öğrencilerin sınıf ortamına getirmiş oldukları bu fikirler fark edilmedikçe ve değiştirilmedikçe eğitimlerinin ilerleyen aşamalarında sıralı bir şekilde birikmekte ve değişime dirençli hâle dönüşmektedir. İstenmeyen bu durumun önüne geçilmesi noktasında öncelikle öğrencilerin mevcut şemalarının sağlam olmasını sağlamak ve bu şemaları tehlikeye atacak herhangi bir yanlış anlamayı ortadan kaldırmak gereklidir. Ancak öğrencide sağlam şemaların oluşmaması durumunda öğrenciye yardımcı olacak stratejilerin kullanımı oldukça önemlidir (Thompson ve Logue, 2006). Butler, Mooney Simmie ve O'Grady (2015) kavramsal değişim stratejisi gibi yanılgıların giderilmesinde etkili olacak stratejilerin işe koşulmasında öğretmenlere büyük sorumluluğun düştüğünü belirtmişlerdir. Çünkü öğrencideki mevcut şemaların ortaya çıkarılması ve öğrencilerin kavram yapılarının belirlenerek gerekli kavramsal değişimin sağlanması hususunda öğretmen, başrol oyuncusu konumundadır. Öğretmenin öğrencideki mevcut kavramsal şemayı belirlemesi ve kavramsal değişimi sağlaması, eş zamanlı biçimde yürütülmesi gereken bir süreçtir. Zira kavram öğreniminin tam olarak gerçekleşmemesi, kavramsal değişim sürecini de zora sokmaktadır.

Türkiye'de kavram öğretimi konusunda yürütülen araştırmalarda kavram yanılgılarına ve yanılgıların giderilmesinde kullanılan değişim stratejilerine değinildiği görülmektedir (Akbal, 2009; Çaycı, 2007; Ecevit ve Özdemir Şimşek, 2017; Güneş, Şener Dilek, Demir, Hoplan ve Çelikoğlu, 2010). İlgili alanyazında kavram ögretimi konusunda kavram karikatürleri (Yurtyapan, Kandemir ve Kandemir, 2017); kavramsal değişim metinleri (Çaycı, 2007); hikâyelendirme (Türkmen ve Ünver, 2012); kavram haritaları ve zihin haritaları (Evrekli, İnel ve Balım, 2012); çoklu yazma etkinlikleri (Akçay, Özyurt ve Akçay, 2014) ile analoji (Aykutlu ve Şen, 2011; Gülçiçek ve Güneş, 2004) kullanımına rastlanmıştır. Bu teknikler hem kavram öğretiminde hem de kavramsal değişimin sağlanmasında kullanılmıştır. İlgili araştırmalardan elde edilen sonuçlar genel olarak yapılandırmacı anlayışa dayalı yöntem ve teknik kullanımının fen kavram öğretiminde ve kavram yanılgılarının tespiti ve giderilmesinde etkin olduğu yönündedir (Çayc1, 2007). Tüm bu sonuçların genel bir analizinin yapılarak hem yapılandırmacı yaklaşımın etkilerinin görülmesi hem de yöntem ve tekniklerin kullanımı konusunda sunulan önerilerin değerlendirilmesi açısından fen eğitiminde kavram öğretimine yeni bir bakış açısı kazandırabilir. Bu nedenle, son 15 yıllık dönemde Türkiye'de fen eğitiminde kavram öğretimi konusunda hangi yönde, nasıl bir ivme olduğunun belirlenmesi ve bu süreçte ortaya çıkan yeni kavram öğretim yöntem ve tekniklerinin belirlenmesi, bu konudaki eksikliklerin giderilmesi ve yeni yaklaşımların tanıtılması açısından yürütülecek bir çalışmanın, fayda sağlayacağı ümit edilmektedir. Daha önce Aydoğan ve Köksal (2017) tarafından ilköğretim düzeyinde 2000-2014 yılları arasında kavram yanılgıları konulu çalışmaların içerik analizi yapılmış, Wassink ve Sadi (2016) tarafından da fen eğitiminde 2005-2014 yılları arasındaki genel eğilimler belirlenmiştir. Aydoğan ve Köksal (2017) tarafından yürütülen çalışma ilköğretim düzeyiyle sınırlandırılırken, Wassink ve Sadi’nin (2016) çalışmasında ilgili yayınlar; yazar bilgisi, fennin çalışma alanları ve konuları, yayınlardaki yöntemler ile genel eğilimler açısından resmedilmiştir. Bunlara ek olarak, bu çalışmada fen eğitiminde kavram öğretimi konusu hem genel hem de özel bir bağlamda ele alınarak belli parametrelerle incelenmeye çalışılmıştır. Dolayısıyla bu çalışmanın amacı, 20052020 yılları arasında Türkiye'de fen eğitiminde kavram öğretimi konulu araştırmaların fen öğretimindeki gelişmelere hangi yönde ne tür bir katkı sağladığı, sonuçlarının neler olduğu ve alanın gelişimi açısından hangi önerilerin sunulduğu saptanarak gelecekte yapılacak olan araştırmalar için başlangıç noktaları oluşturmaktır. Bu amaçla aşağıdaki sorulara yanıt aranmıştır:

1. Fen eğitiminde kavram öğretimi konulu araştırmaların yıllara ve yayın türüne göre dağılımı nasıldır?

2. Fen eğitiminde kavram öğretimi konulu araştırmalar hangi amaç ve konu temalarında toplanmıştır?

3. İlgili araştırmalarda tercih edilen yöntem ve desen, örneklem, veri toplama araçları, kavram öğretimiyle ilgili yöntem/teknikler ile veri analiz yöntemleri hangi temalarda toplanmıştır?

4. İlgili araştırmalarda ulaşılan sonuçlar ve sunulan öneriler hangi temalarda toplanmıştır?

\section{Yöntem}

\section{Araştırmanın Deseni}

$\mathrm{Bu}$ çalışmada sistematik derleme yöntemi kullanılmıştır. Sistematik derleme; "aynı konuda yapılmış olan araştırma sonuçlarını sentezlemek ve özetlemek için geliştirilmiş bir araştırma yöntemidir" (Gökdemir ve Dolgun, 2020, s. 192). Sağlık sektöründen eğitim alanına pek çok disiplinde kullanılan sistematik derleme, doksanlı yıllardan bu yana uluslararası kuruluşlar tarafından yürütülen eğitim araştırmalarında da sıklıkla tercih edilen bir yöntem olmuştur (Bearman ve diğ., 2012). Sistematik derleme ya da sistematik alanyazın derleme olarak bilinen bu yöntemde, çalışılan konu ya da kavramla ilgili olarak yayımlanmış araştırmaların kapsamlı bir biçimde taranması, dâhil edilme ve dışarda bırakılma ölçütlerinin belirlenmesi, böylece araştırmaların kalitesi değerlendirilerek hangi araştırmaların derlemeye alınacağının belirlenmesi söz konusudur (Karaçam, 2013). Kapsama alınacak araştırmaların belirlenmesinin ardından nitel veya nicel tasarımlı araştırmalardan elde edilen ortak kanıtların sentezlenmesi ve son olarak ilgili bulgulardan hareketle okuyucuya bir sonucun sunulması esastır 
(Çam ve Bilge, 2013). Sistematik derleme yöntemi kullanılırken uyulması gereken yönergeler bu çalışma ile ilişkilendirilerek aşağıda adım adım açıklanmıştır.

\section{Verilerin Toplanması ve Analizi}

Bu çalışmada, Türkiye'de 2005-2020 yılları arasında fen eğitiminde kavram öğretimi konulu araştırmaları incelemek amacıyla ulusal veri tabanları taranmıştır. Araştırmaların, özellikle bu tarihler aralığında seçilmiş olmasının nedeni, son 15 yılda yayımlanan fen eğitiminde kavram öğretimi konusundaki güncel araştırmaların ele alınmak istenmesidir. Ayrıca Türkiye'de 2005 yılında yapılan program değişikliği ve yeni programda yapılandırmacı anlayışın yer alması nedeniyle temele alınan bu anlayışın kavram öğretimi üzerindeki etkilerinin de incelenmesi hedeflenmiștir. Bu amaçla Google Akademik, TÜBİTAK ULAKBIM, ASOS İndeks ve Türk Eğitim İndeksi ardından da YÖK Ulusal Tez Merkezi incelenmiştir. Bu veri tabanlarının açık erişim imkânı sunması, Türkçe yayımlanan eserleri barındırması ve ücretli üyelik gerektirmemesi gibi gerekçelerden ötürü daha fazla yayına ulaşılabileceği düşünülmüş ve ilgili tarama, bu veri tabanları üzerinden gerçekleştirilmiştir. Taramalarda anahtar kelime olarak; fende kavram, kavram öğretimi, fende kavram öğretimi ifadeleri kullanılmıştır. İlgili taramalarda ulaşılan kitaplar, araştırma ve ders raporları ile özet ya da tam metin bildiriler çalışmaya dâhil edilmemiştir. Aynı yazarın tezinden ürettiği yayın olması halinde ise sadece ilgili makale incelemeye alınmıştır. Bu şekilde Ek A’daki toplam 57 adet araştırmaya ulaşılmıştır.

Alanyazın tarama işlemi Aralık 2019 tarihinden Şubat 2020 tarihine kadar devam etmiştir. Taramada ulaşılan araştırmaların ilgili parametrelere aktarımı, Şubat ve Mart 2020 tarihlerinde gerçekleştirilmiştir. Bu nedenle 2020 Mart ayından sonra yayımlanan araştırmalar kapsam dışı tutulmuştur. İlgili araştırmaların, mevcut çalışma bağlamına uygunluğu konusunda Mart ayında uzman görüşüne başvurulmuş ve çalışmanın bulgular kısmı, Nisan 2020 tarihinde yazılmaya başlanmıştır. Tarama sonucunda ulaşılan araştırmalar tam metin olarak kayıt altına alınmıştır. Bu araştırmaların her biri belli bir parametre altında Excel'de kodlanmıştır. Bu parametreler; yayın yılı, yayın türü, amaç, yöntem/desen, örneklem, veri toplama aracı, veri analiz yöntemi, incelenen konu, sonuç ve öneri olarak belirlenmiştir. Bu parametreler ilgili alanyazında pek çok kez kullanılmıştır (Bağ ve Çalık, 2017, 2018; Gül ve Sözbilir, 2015; Yıldırım, Çalık ve Özmen, 2016). Çalışmada ayrıca fen eğitiminde kullanılan kavram öğretim tekniği/yöntemi başlığı da ele alınmıştır. Böylece çalışma sonunda daha kapsamlı verilere ulaşılması hedeflenmiştir. Çalışmaya dâhil edilen araştırmalar, bu parametreler doğrultusunda incelenip kodlar oluşturulmuştur. Kodların birleştirildiği temalar ise aynı zamanda bu parametreyi oluşturan bileşenlerdir.

\section{Geçerlik Güvenirlik Önlemleri}

Sistematik derlemede geçerlik ve güvenirliğin sağlanması önemli bir meseledir (Karaçam, 2013). Bu çalışmada da güvenirliğin sağlanması için fen eğitimi alanında doktorasını tamamlamış bir uzmandan yardım alınmıştır. Uzmandan, ilgili çalışmaya dâhil edilen 10 farklı araştırmayı kodlaması istenmiş ve uzmanın kodları ile bu çalışmanın yazarı tarafından hazırlanan kodların uyuşum yüzdesine bakılmıştır. Sandelowski (1998) çalışmalarda güvenirliğin bu şekilde de sağlanabileceğini belirtmektedir. Buna dayanarak, çalışmanın güvenirliğinin sağlanması açısından, hem nitel alana hâkim hem de fen eğitimi çalışmaları yürüten bir uzman seçimi ile tüm veriyi temsil eden bir kısmın gönderimi yapılmış ve görüş alınmıştır. Bu uyuşum yüzdesi Miles ve Huberman’ın (1994) önerdiği güvenirlik formülü ile hesaplanmış ve \% 99 olarak hesaplanmıştır. Bu sonuç, kodlayıcı güvenirliğinin yeterli düzeyde olduğunu göstermektedir. Çalışmanın geçerliliğinin sağlanması amacıyla araştırmacı, sistematik derleme sürecinin her adımını detaylı bir biçimde açıklamaya özen göstermiştir.

\section{Bulgular}

Bu çalışma kapsamında incelenen araştırmalar, belirlenen parametrelere göre kodlanmış ve temalara ulaşılmıştır. Temalara ait bulgular sırasıyla açıklanmıştır. İlk olarak, araştırmaların yayın yılı, türü ve yeri Tablo 1'de sunulmuştur. 
Tablo 1

Yayın Yıll, Türü ve Yerine İlişkin Kodlar ve Frekansları

\begin{tabular}{|c|c|c|c|}
\hline Yayın Yilı & Yayın Türü & Yayın Yeri & $f$ \\
\hline 2005 & Makale & Hacettepe Üniversitesi Eğitim Fakültesi Dergisi (1) & 1 \\
\hline 2006 & Makale & $\begin{array}{l}\text { Türk Fen Eğitimi Dergisi(1), Hacettepe Üniversitesi Eğitim Fakültesi } \\
\text { Dergisi (1), Eğitim ve Bilim (1) }\end{array}$ & 3 \\
\hline \multirow[t]{2}{*}{2007} & Yüksek Lisans T. & Ankara Üniversitesi (1) & \\
\hline & Makale & $\begin{array}{l}\text { Gazi Üniversitesi Gazi Eğitim Fakültesi Dergisi (1), Abant İzzet Baysal } \\
\text { Üniversitesi Eğitim Fakültesi Dergisi (1), Dokuz Eylül Üniversitesi Buca } \\
\text { Eğitim Fakültesi Dergisi (1) }\end{array}$ & 4 \\
\hline \multirow[t]{2}{*}{2008} & Yüksek Lisans T. & Gazi Üniversitesi (1) & \\
\hline & Makale & $\begin{array}{l}\text { Hacettepe Üniversitesi Eğitim Fakültesi Dergisi (1), Ege Eğitim Dergisi } \\
\text { (1), İlköğretim Online (1) }\end{array}$ & 4 \\
\hline \multirow[t]{2}{*}{2009} & Yüksek Lisans T. & Marmara Üniversitesi (1), Gazi Üniversitesi (1) & \\
\hline & Makale (2) & $\begin{array}{l}\text { Eğitim Bilimleri Dergisi (1), Necatibey Eğitim Fakültesi Elektronik Fen ve } \\
\text { Matematik Eğitimi Dergisi (1) }\end{array}$ & 4 \\
\hline \multirow[t]{2}{*}{2010} & \multirow[t]{2}{*}{$\begin{array}{l}\text { Yüksek Lisans T. } \\
\text { Makale }\end{array}$} & $\begin{array}{l}\text { Selçuk Üniversitesi (1), Hacettepe Üniversitesi (1), Zonguldak Karaelmas } \\
\text { Üniversitesi (1) }\end{array}$ & \multirow{2}{*}{5} \\
\hline & & $\begin{array}{l}\text { Batı Anadolu Eğitim Bilimleri Dergisi (1), Türk Eğitim Bilimleri Dergisi } \\
\text { (1) }\end{array}$ & \\
\hline 2011 & Makale & $\begin{array}{l}\text { Necatibey Eğitim Fakültesi Elektronik Fen ve Matematik Eğitimi Dergisi } \\
\text { (2), Dicle Üniversitesi Ziya Gökalp Eğitim Fakültesi Dergisi (1), Erciyes } \\
\text { Üniversitesi Sosyal Bilimler Enstitüsü Dergisi (1), Uşak Üniversitesi } \\
\text { Sosyal Bilimler Dergisi (1), Gaziantep Üniversitesi Sosyal Bilimler Dergisi } \\
\text { (1), Iğdır Üniversitesi Fen Bilimleri Enstitüsü Dergisi (1), Mustafa Kemal } \\
\text { Üniversitesi Sosyal Bilimler Enstitüsü Dergisi (1) }\end{array}$ & 8 \\
\hline 2012 & Makale & $\begin{array}{l}\text { Türk Eğitim Dergisi (1), Mehmet Akif Ersoy Üniversitesi Ĕ̆itim Fakültesi } \\
\text { Dergisi (1), Adıyaman Üniversitesi Sosyal Bilimler Enstitüsü Dergisi (1) }\end{array}$ & 3 \\
\hline 2013 & Makale & $\begin{array}{l}\text { Türk Fen Eğitimi Dergisi (1), Ahi Evran Üniversitesi Kırşehir Eğitim } \\
\text { Fakültesi Dergisi (2), Gazi Üniversitesi Gazi Eğitim Fakültesi Dergisi (1), } \\
\text { Eğitim Bilimleri Dergisi (1), Karaelmas Eğitim Bilimleri Dergisi (1) }\end{array}$ & 6 \\
\hline \multirow[t]{2}{*}{2014} & Doktora $\mathrm{T}$. & Marmara Üniversitesi (1) & \\
\hline & Makale & $\begin{array}{l}\text { Marmara Üniversitesi Atatürk Eğitim Fakültesi Eğitim Bilimleri Dergisi } \\
\text { (1), Adıyaman Üniversitesi Sosyal Bilimler Enstitüsü Dergisi (1), } \\
\text { Uluslararası Türk Eğitim Bilimleri Dergisi (1), Türk Fen Eğitimi Dergisi } \\
\text { (1), Bayburt Eğitim Fakültesi Dergisi (1), Marmara Üniversitesi Atatürk } \\
\text { Eğitim Fakültesi Eğitim Bilimleri Dergisi (1) }\end{array}$ & 7 \\
\hline 2015 & - & - & 0 \\
\hline \multirow[t]{3}{*}{2016} & Yüksek Lisans T. & Süleyman Demirel Üniversitesi, Erzincan Üniversitesi (1) & \\
\hline & Doktora $\mathrm{T}$. & Uludağ Üniversitesi (1), Gazi Üniversitesi & 5 \\
\hline & Makale & Gazi Üniversitesi Gazi Eğitim Fakültesi Dergisi (1) & \\
\hline \multirow[t]{2}{*}{2017} & Yüksek Lisans T. & Pamukkale Üniversitesi (1) & \\
\hline & Makale & $\begin{array}{l}\text { Ege Ĕ̆itim Dergisi (1), Araştırma Temelli Etkinlik Dergisi (1), İlköğretim } \\
\text { Online (1) }\end{array}$ & 4 \\
\hline 2018 & Yüksek Lisans T. & Necmettin Erbakan Üniversitesi(1), Mehmet Akif Ersoy Üniversitesi (1) & 2 \\
\hline \multirow[t]{2}{*}{2019} & Makale & Bolu Abant İzzet Baysal Üniversitesi Eğitim Fakültesi Dergisi (1) & 1 \\
\hline & Toplam & & 57 \\
\hline
\end{tabular}

Tablo 1'de yer alan kodlama sonucuna göre 2015 y1lında fen eğitiminde kavram öğretimi konusunda herhangi bir araştırmaya ulaşılamazken 2005 ve 2019 yıllarında 1'er; 2018 yılında 2; 2006 ve 2012 yıllarında 3'er; 2007, 2008, 2009 ve 2017 yıllarında 4'er; 2010 ve 2016 yıllarında 5'er; 2013 yılında 6; 2014 yılında 7 ve 2011 yılında 8 adet araştırmaya ulaşılmıştır. Bu araştırmaların 42'si makale, 12'si yüksek lisans tezi ve 3'ü doktora tezidir. Ulaşılan makalelerin, farklı türlerdeki dergilerde yayımlandığg görülmektedir. Bununla beraber yüksek lisans ve doktora 
tezlerinin 3'ünün Gazi Üniversitesi, 2'sinin Marmara Üniversitesinde, diğerlerinin ise Ankara Üniversitesi, Selçuk Üniversitesi, Hacettepe Üniversitesi, Zonguldak Karaelmas Üniversitesi, Süleyman Demirel Üniversitesi, Erzincan Üniversitesi, Uludağ Üniversitesi, Pamukkale Üniversitesi, Necmettin Erbakan Üniversitesi ve Mehmet Akif Ersoy Üniversitesinde yürütülmüş olduğu görülmüştür.

$\mathrm{Bu}$ çalışmada incelenen araştırmaların amaç ve incelenen konu temalarına yönelik oluşturulan kod ve frekans dağılımları ise Tablo 2'de sunulmuştur.

Tablo 2

Çalışmaların Amaç ve İncelenen Konu Temalarına İlişkin Kodları ve Frekansları

\begin{tabular}{|c|c|c|c|}
\hline Temalar & Kategoriler & Kodlar $(f)$ & Frekans \\
\hline \multirow{7}{*}{ Amaç } & \multirow{3}{*}{ Kavram yanılgılarının incelenmesi } & Kavram yanılgisının tespiti & 5 \\
\hline & & Kavram yanılgisının giderilmesi & 11 \\
\hline & & Kavram yanılgısının tespiti ve giderilmesi & 6 \\
\hline & $\begin{array}{l}\text { Kavram öğretiminin bazı değişkenlere } \\
\text { etkisinin saptanması }\end{array}$ & $\begin{array}{l}\text { Öğrenme ürünleri (3), Akademik başarı (15), Kavram } \\
\text { öğrenme düzeyi (7), Sorgulayıc öğrenme becerisi (2), } \\
\text { Argümantasyon kalitesi (1), Fene yönelik tutum (6), } \\
\text { Fene yönelik motivasyon (2), Bilimsel süreç becerileri } \\
\text { (1) }\end{array}$ & 37 \\
\hline & $\begin{array}{l}\text { Kavram öğretimi } \\
\text { strateji/yöntem/tekniklerin } \\
\text { tanıtılması/incelenmesi/karş1laştırılması }\end{array}$ & $\begin{array}{l}\text { Kavram karikatürü-açık uçlu soruları karşılaştırma } \\
\text { (1), Kavram haritaları-kavramsal değişim metinlerinin } \\
\text { karşılaştırılması (1), Analoji-tahmin-gözlem- } \\
\text { açılama-kavram karikatürü karşılaştırması (1), } \\
\text { Kavram haritası-anlam çözümleme tablosu } \\
\text { karşılaştırması (1) }\end{array}$ & 4 \\
\hline & Diğer & $\begin{array}{l}\text { Örnek etkinlik tasarımı (2), öğrencilerin / } \\
\text { öğretmenlerin kavram öğretimine ilişkin görüşlerinin } \\
\text { belirlenmesi (3) }\end{array}$ & 5 \\
\hline & Toplam & & $68^{*}$ \\
\hline \multirow{6}{*}{$\begin{array}{l}\text { İncelenen } \\
\text { Konu }\end{array}$} & Fizik & $\begin{array}{l}\text { Momentum ve impuls (2), Ses ve/veya 1şık (7), } \\
\text { Elektrik akımı (6), Basınç (1), Kuvvet ve hareket (1) }\end{array}$ & 17 \\
\hline & Kimya & $\begin{array}{l}\text { Is1 ve sıcaklık (3), Madde (4), Buharlaşma ve } \\
\text { kaynama (1), Mol (1), Çözünürlük (1), Kimyasal } \\
\text { denge (1), Gazlar (1) }\end{array}$ & 12 \\
\hline & Biyoloji & $\begin{array}{l}\text { Hücre (7), Canlılar (6), Biyoçeşitlilik (1), Bitkiler (2), } \\
\text { Dolaşım sistemi (1), Dokular (1), Solunum sistemi } \\
\text { (1), Asitler ve bazlar (1) }\end{array}$ & 20 \\
\hline & Çevre & Sera etkisi ve küresel ısınma (1), Işık kirliliği (1) & 2 \\
\hline & Diğer & Genel konular (3), Konusu açıkça belirtilmeyenler (3) & 6 \\
\hline & Toplam & & 57 \\
\hline
\end{tabular}

* işareti ile belirtilen yerlerde ulaşılan frekans değerlerinin fazla olmasının nedeni aynı çalışmada birden fazla amaç ve konu belirtilmiş olmasından kaynaklanmaktadır.

Tablo 2'ye göre araştırmaların toplam 22 tanesinin kavram yanılgıları ile ilgili olduğu; 37 tanesinin kavram öğretim tekniklerinin farklı değişkenler (akademik başarı, tutum, motivasyon gibi) üzerindeki etkisini inceleyen araştırmalar olduğu; 4'ünün fen eğitiminde kavram öğretim yöntem/tekniklerinin tanıtılması, karşılaştırılması ve bir ölçme aracı olarak kullanılıp kullanılamayacağı ile ilgili olduğu; diğer kategorisindeki 2 araştırmanın yöntem/tekniklerin kullanımıyla ilgili örnek etkinlik tasarımı içerdiği ve 3 araştırmanın bu yöntem/tekniklerle ilgili öğretmen/öğrenci görüşüne başvurduğu görülmektedir.

İncelenen konu bağlamları ile ilgili temalar incelendiğinde ise ilgili araştırmaların 21 tanesinin biyoloji; 16 tanesinin fizik; 15 tanesinin kimya; 2 tanesinin çevre ve diğer kategorisindeki 3 araştırmanın genel konularla ilgili olduğu görülmektedir. 3 araştırmada ise konu açıkça belirtilmemiştir.

İlgili araştırmalarda tercih edilen yöntem ve desen, örneklem, veri toplama araçları, kavram öğretimiyle ilgili yöntem/teknikler ile veri analiz yöntemlerine ilişkin kodlar ve frekanslar Tablo 3’te sunulmuştur. 
Tablo 3

Çalışmaların Yöntem/Desen, Örneklem Düzeyi, Veri Toplama Araçları, Veri Analiz Yöntemine İlişkin Kodları ve Frekansları

\begin{tabular}{|c|c|c|c|c|}
\hline \multirow[t]{2}{*}{ Temalar } & \multirow{2}{*}{$\begin{array}{l}\text { Kategoriler } \\
\text { Nicel }\end{array}$} & \multicolumn{2}{|l|}{ Kodlar $(f)$} & \multirow{2}{*}{$\begin{array}{c}\text { Frekans } \\
41\end{array}$} \\
\hline & & Deneysel & $\begin{array}{l}\text { Zayıf deneysel desen (3), yarı } \\
\text { deneysel desen (38) }\end{array}$ & \\
\hline \multirow{10}{*}{ Yöntem/Desen } & & Tarama & & 2 \\
\hline & Nitel & \multirow{4}{*}{\multicolumn{2}{|c|}{$\begin{array}{l}\text { Durum çalışması } \\
\text { Aksiyom araştırması } \\
\text { Olgu bilim } \\
\text { Desen belirtilmemiş }\end{array}$}} & 1 \\
\hline & & & & 1 \\
\hline & & & & 1 \\
\hline & & & & 4 \\
\hline & Karma desen & \multicolumn{2}{|c|}{$\begin{array}{l}\text { Nicel - deneysel (1) } \\
\text { Nitel - durum çalışması (1) }\end{array}$} & 2 \\
\hline & \multicolumn{3}{|c|}{ Alanyazın taraması } & 2 \\
\hline & \multicolumn{3}{|l|}{ Belirtilmemiş } & 2 \\
\hline & \multicolumn{3}{|l|}{ Diğer } & 1 \\
\hline & \multicolumn{3}{|l|}{ Toplam } & 57 \\
\hline \multirow{7}{*}{ Örneklem } & \multicolumn{3}{|c|}{ İlkokul öğrencileri } & 2 \\
\hline & \multicolumn{3}{|c|}{ Ortaokul öğrencileri } & 29 \\
\hline & \multicolumn{3}{|c|}{ Lise öğrencileri } & 9 \\
\hline & \multicolumn{3}{|c|}{ Öğretmen adayı } & 16 \\
\hline & \multicolumn{3}{|c|}{ Öğretmen } & 1 \\
\hline & \multicolumn{3}{|l|}{ Belirtilmemiş } & 1 \\
\hline & \multicolumn{3}{|l|}{ Toplam } & $58^{*}$ \\
\hline \multirow{10}{*}{ Veri Toplama Araçları } & \multirow{2}{*}{\multicolumn{3}{|c|}{$\begin{array}{l}\text { 2-3 aşamalı başarı / kavram testleri } \\
\text { Görüşme formları }\end{array}$}} & 40 \\
\hline & & & & 14 \\
\hline & \multicolumn{3}{|c|}{ Açık uçlu sorular } & 4 \\
\hline & \multicolumn{3}{|c|}{ Kavram öğretiminde kullanılan araçlar } & 16 \\
\hline & \multicolumn{3}{|c|}{ Tutum ölçekleri } & 19 \\
\hline & \multicolumn{3}{|c|}{ Motivasyon ölçekleri } & 2 \\
\hline & \multicolumn{3}{|c|}{ Beceri ölçekleri } & 3 \\
\hline & Gözlem/günlü & rmları & & 3 \\
\hline & Mantıksal düş & ne yeteneği t & & 3 \\
\hline & Toplam & & & $104^{*}$ \\
\hline & Nitel & & $\begin{array}{l}\text { Betimsel analiz } \\
\text { İçerik analizi }\end{array}$ & $\begin{array}{c}10 \\
6\end{array}$ \\
\hline & Nicel & & Tanımlayıcı istatistiksel analiz & 11 \\
\hline & & & $t$ testi & 36 \\
\hline & & & ANOVA & 6 \\
\hline & & & ANCOVA & 2 \\
\hline Veri Analiz Yöntemi & & & MANCOVA & 1 \\
\hline & & & Mann Whitney $U$ testi & 8 \\
\hline & & & Wilcoxon işaretli sıralar testi & 6 \\
\hline & & & Korelasyon analizi & 3 \\
\hline & & & Kruskal Wallis testi & 1 \\
\hline & Belirtilmemiş & & & 3 \\
\hline & Toplam & & & $93^{*}$ \\
\hline
\end{tabular}

*Frekans değerlerinin fazla olması, aynı çalışmada birden fazla amaç, örneklem düzeyi, veri toplama aracı, fen öğretiminde kullanılan yöntem/teknik, veri analiz yöntemi ve konu seçilmiş olmasından kaynaklanmaktadır.

Tablo 3'te araştırmaların yöntemleri ile desenleri incelendiğinde en fazla nicel yöntemin kullanıldığı görülmektedir. Bu çalışmalarda genellikle ön test-son test kontrol gruplu yarı deneysel desenler tercih edilmiştir $(f=38)$. Nitel araştırma desenlerini tercih oranının az olduğu $(f=9)$ görülmektedir. Bununla birlikte araştırmaların 1 tanesinde hem nicel hem de nitel araştırma yönteminin birlikte kullanıldığı belirtilmiştir. İlgili araştırma tek bir çatı altına yerleştirilememiş ve “diğer” olarak kodlanmıştır. İncelenen araştırmaların 2'sinde alanyazın taraması kullanılırken 2 araştırmanın yöntem ve deseni ise belirtilmemiştir. 
Tablo 3 'te araştırmaların örneklemleri incelendiğinde, büyük bir çoğunluğunun $(f=29)$ ortaokul kademesinde yürütüldüğü görülmektedir. Ardından 16 araştırma ile öğretmen adayları; 9 araştırma ile lise öğrencileri; 2 araştırma ile ilkokul öğrencileri ve 1 araştırma ile öğretmenlerin örneklem grubunu oluşturduğu tespit edilmiştir. 1 araştırmada ise örneklem hakkında bilgi verilmemiştir.

Araştırmalarda veri toplama aracı olarak en fazla 2-3 aşamalı başarı ya da kavram testlerinin kullanıldığı $(f=40)$ görülmektedir. Bu veri toplama aracını tutum ölçekleri $(f=19)$, kavram öğretiminde kullanılan diğer araçlar $(f=$ 16) ile görüşme formları $(f=14)$ takip etmiştir. Araştırmalarda genellikle veri çeşitlemesine gidildiğinden birden fazla veri toplama aracının kullanıldığı görülmüştür. Ayrıca araştırmalarda motivasyon ölçekleri $(f=2)$ ile beceri ölçekleri, gözlem, günlük formlar, mantıksal düşünme yeteneği testi $(f=3)$ ve açık uçlu sorular $(f=4)$ kullanılmıştır.

Araştırmalarda nicel yöntemlerin fazla kullanılmasına bağlı olarak nicel veri analiz yöntemlerinin de sayıca fazla olduğu $(f=76)$ görülmektedir. Araştırmaların büyük bir kısmında cinsiyet faktörü incelenmiş ve deneysel araştırmalarda uygulama öncesi ve sonrası değişimlere bakılmıştır. Dolayısıyla bu durum $t$ testinin fazlaca kullanımına yol açmıştır $(f=36)$. Araştırmaların 3 'ünde veri analiz yöntemi açıklanmamakla beraber, ileri düzey istatistik analizlerinin de yapılmadığ 1 görülmüştür. Nitel analiz yöntemlerine bakıldığında ise, betimsel analizin $(f$ $=10)$, içerik analizinden daha fazla tercih edildiği görülmüştür $(f=6)$. İncelenen araştırmaların sonuçlarını ve önerilerini kapsayan temalara ilişkin kodlar ile frekansları Tablo 4’te sunulmuştur.

Tablo 4

Çalışmaların Sonuç ve Öneri Temalarına İlişkin Kodları ve Frekansları

\begin{tabular}{|c|c|c|c|}
\hline Tema & & Kod & Frekans \\
\hline \multirow{9}{*}{ Sonuç } & Kavram yanılgısını belirlemeyle ilgili sonuç & Olumlu etki & 4 \\
\hline & Kavram yanılgısını gidermeyle ilgili sonuç & Olumlu etki & 12 \\
\hline & $\begin{array}{l}\text { Kavram yanılgısını belirleme ve gidermeyle } \\
\text { ilgili sonuç }\end{array}$ & Olumlu etki & 4 \\
\hline & \multirow{3}{*}{$\begin{array}{l}\text { Kavram öğretim yöntem/tekniğinin } \\
\text { değişkenler üzerindeki etkisiyle ilgili sonuç }\end{array}$} & Olumlu etki & 33 \\
\hline & & Olumsuz etki & 1 \\
\hline & & Nötr etki & 12 \\
\hline & Diğer & Betimsel sonuç & 10 \\
\hline & Belirtilmemiş & & 1 \\
\hline & Toplam & & $77 *$ \\
\hline \multirow{12}{*}{ Öneri } & \multirow[t]{2}{*}{ Öğretmenlere yönelik öneriler } & $\begin{array}{l}\text { Tekniğin diğer disiplinlerde / farklı kademelerde de } \\
\text { kullanımı }\end{array}$ & 13 \\
\hline & & Kavram öğretim tekniklerinin sıklıkla kullanılması & 14 \\
\hline & \multirow{4}{*}{$\begin{array}{l}\text { Milli Eğitim Bakanlığına (MEB) yönelik } \\
\text { öneriler }\end{array}$} & $\begin{array}{l}\text { Öğretmenlere yönelik hizmet içi eğitimlerin } \\
\text { düzenlenmesi }\end{array}$ & 13 \\
\hline & & $\begin{array}{l}\text { Öğretmenlere yönelik beceri geliştirme kurslarının } \\
\text { düzenlenmesi }\end{array}$ & 2 \\
\hline & & $\begin{array}{l}\text { Ders kitaplarına daha fazla örnek etkinliklerin } \\
\text { konulması }\end{array}$ & 12 \\
\hline & & Uygulamalı eğitimlere ağırlık verilmesi & 3 \\
\hline & \multirow[t]{2}{*}{ Öğretmen eğitimcilerine yönelik öneriler } & $\begin{array}{l}\text { Öğretmen adaylarının kavram yapılarının ve } \\
\text { yanılgılarının belirlenmesi }\end{array}$ & 1 \\
\hline & & $\begin{array}{l}\text { Daha uzun sürelerde ve farklı örneklemlerde } \\
\text { araştırma yapılması }\end{array}$ & 17 \\
\hline & \multirow[t]{2}{*}{ Araştırmacılara yönelik öneriler } & $\begin{array}{l}\text { Diğer yöntem ve tekniklerle birlikte etkilerinin } \\
\text { incelenmesi }\end{array}$ & 6 \\
\hline & & $\begin{array}{l}\text { Yöntem ve tekniklerin değişkenler üzerindeki } \\
\text { etkilerinin incelenmesi }\end{array}$ & 6 \\
\hline & Açık bir öneri sunulmamış & & 5 \\
\hline & Toplam & & $92^{*}$ \\
\hline
\end{tabular}


Tablo 4'te fen eğitiminde kavram öğretimi konulu araştırmalardan elde edilen sonuçlar ile araştırmalarda sunulan öneriler özetlenmiştir. Buna göre sonuçların 16'sı kavram yanılgılarıyla; 46'sı kullanılan kavram öğretim tekniklerinin diğer değişkenler üzerindeki etkisiyle; 10’u ise betimsel sonuçlarla ilgilidir. İlgili değişkenlerin işe koşulduğu araştırmalarda kavram öğretim yöntem/tekniklerinin büyük oranda $(f=33)$ olumlu yönde etki ettiği, sadece bir tanesinde olumsuz yönde etki olduğu, 12 tanesinde ise herhangi bir etkinin olmadığ 1 görülmektedir; 1 araştırmada sonuca net olarak yer verilmemiştir. Öneriler temasında öğretmenlere ve MEB'e yönelik olarak 27; öğretmen eğitimcilerine yönelik olarak 4; araştırmacılara yönelik olarak 29 öneri sunulmuştur. Araştırmaların 5 'inde ise herhangi bir öneri sunulmamıştır.

Mevcut çalışma kapsamında daha kapsamlı sonuçların elde edilmesine hizmet etmesi amacıyla ilgili araştırmalarda kullanılan kavram öğretim yöntem/teknikleri de ele alınmıştır. Elde edilen bulgular Tablo 5 'te özetlenmiştir.

Tablo 5

Fen Ĕ̆itiminde Kullanılan Kavram Öğretim Yöntem/Teknik Temasına İlişkin Kodlar ve Frekansları

\begin{tabular}{llc}
\hline Tema & Kod & Frekans \\
\hline & Kavram haritası & 22 \\
& Kavram karikatürü & 17 \\
& Tahmin-Gözlem-Açıklama (TGA) & 5 \\
Fen Eğitiminde Tercih Edilen Kavram & Analoji & 6 \\
Öğretim Yöntemi/Tekniği & Kavramsal değişim metni & 12 \\
& Anlam çözümleme tablosu & 1 \\
& Zihin haritası & 3 \\
& Kavram çarkı diyagramı & 1 \\
& Diğer & 4 \\
& Toplam & $71^{*}$ \\
\hline
\end{tabular}

Tablo 5'te görülen fen eğitiminde kavram öğretimi konulu araştırmaların hangi kavram öğretimi yöntem / tekniğini tercih ettiğiyle ilgili oluşturulan kodlar incelendiğinde, ilgili araştırmalarda en fazla kavram haritasına yer verildiği $(f=22)$ görülmektedir. Kavram haritalarını kavram karikatürleri $(f=17)$; kavramsal değişim metinleri $(f=12)$; analoji $(f=6)$ ve TGA $(f=5)$ takip etmiştir. Bu teknikler dışında farklı tekniklere de yer verilen araştırmalar (anlam çözümleme tablosu, kavram çarkı diyagramı vb.) olduğu görülmektedir.

\section{Sonuç ve Tartışma}

Bu çalışmada, fen eğitiminde kavram öğretimi ile ilgili alanyazında ulaşılabilen toplam 57 araştırma incelenmiştir. Çalışmada ilk olarak geçirdiğimiz son 15 yıllık süreçte, 2015 yılı dışında, birbirine yakın sayıda araştırmaların yürütüldüğü görülmüştür. Fakat 2005 ve 2019 yıllarında bu değerin altında kalınarak sadece 1'er araştırma olduğu tespit edilmiştir (Artun, Günseven ve Temur, 2019; Başer ve Çataloğlu, 2005). Bu yıllar aynı zamanda MEB (2005; 2018) tarafından fen bilimleri dersi öğretim programında değişikliklerin yapıldığı dönemlerdir. Bilindiği üzere MEB (2005) tarafından fen ve teknoloji dersi için 5, 6, 7 ve 8. sınıflarda öğrenci merkezli yaklaşımlar tanıtılmış, 2013 yılında program gözden geçirilerek dersin adı fen bilimleri olarak güncellenmiş ve ilkokul 3 ve 4 . sınıflarda da fen öğretiminin yapılmasına karar verilmiştir (MEB, 2013). 2018 yılında fen bilimleri programında yeniden değişikliğe gidilmiştir. Dolayısıyla bu yıllarda (2005 ve 2019) fen eğitiminde kavram öğretimi konusundaki araştırmaların sayıca az olması, yeni öğretim programının yapısının anlaşılmaya çalışılması ve ilgili araştırmaların hazırlık aşamalarının gerçekleştirilmesine bağlanabilir. 2015 yılında fen eğitiminde kavram öğretimi konusunda herhangi bir araştırmaya rastlanılmamış olmasının sebebinin ise özellikle 2014 yılından itibaren ülkemizde yoğun bir biçimde STEM eğitimi ve uygulamalarına yönelik araştırma eğiliminin olduğu düşünülmektedir. Nitekim Herdem ve Ünal (2018) STEM eğitimi üzerine yürütülen araştırmaların meta sentezini yaptıkları çalışmalarında özellikle 2015 ve 2016 yıllarında oldukça fazla yayın olduğunu tespit etmişlerdir. Dolayısıyla fen öğretiminde ortaya çıkan bu yeni çalışma alanı, araştırmacıların kavram öğretimi konusuna ilgisini azaltmış olabilir.

Çalışmada 42 makale, 12 yüksek lisans tezi ve 3 doktora tezine ulaşılmıştır. Doktora tezlerinin sayıca bu kadar az olmasının nedeni, yukarıda belirtildiği üzere, fen eğitiminde yeni bir araştırma alanının ortaya çıkışıyla ilgili olabilir. Çünkü ulaşılan doktora tezlerinin 2 tanesi 2016 y1lında (Güngör, 2016; Turan Oluk, 2016), 1'i ise 2014 (Sarı, 2014) yılında yürütülmüştür. İlgili konu bağlamında az sayıda doktora tezine ulaşılmış olması özellikle doktora tez yazarlarının araştırmalarını açık erişime açmak için ileri tarihleri belirlemiş olmalarından da kaynaklanmıştır. İdin ve Kaptan (2017) da, yenilenen fen öğretim programlarına göre hazırlanan doktora tezlerini inceledikleri çalışmalarında özellikle 2014 yılından sonraki doktora tezlerine ulaşmada sıkıntı yaşadıklarını dile 
getirmişlerdir. Dolayısıyla ulaşılamayan tezler kapsam dışı tutulduğundan az sayıda doktora tezi incelemeye alınabilmiştir.

$\mathrm{Bu}$ çalışmanın amaç temasında incelenen araştırmaların en fazla, kavram öğretiminde kullanılan tekniklerin bazı değişkenler üzerindeki etkilerini incelemeyi hedefledikleri görülmüştür. Bu değişkenler genellikle akademik başarı (Akçay ve diğ., 2014; Aksoy, 2010; Bilen ve Köse, 2012; Çakmak, Gürbüz ve Kaplan, 2012; Çinici ve diğg., 2014; Demir, 2016; Gölgeli ve Saraçoğlu, 2011; Güngör, 2016; Kavak, 2009; Temelli ve Kurt, 2011; Uyanık ve Dindar, 2016); kavram öğrenme düzeyi (Akçay ve diğ., 2014; Artun ve diğ.,, 2019; Atasoy, Tekbıyık ve Gülay, 2013; Bayram ve Ersoy, 2014; Bilen ve Köse, 2012; Candan, Türkmen ve Çardak, 2006); öğrenme ürünleri (Çetinkaya ve Taş, 2011; Çinici ve diğ., 2014; Özyılmaz Akamca ve Hamurcu, 2009); tutum ve motivasyon (Çaycı, 2007; Evrekli ve diğ., 2012; İnel ve Balım, 2011; Özdemir ve Dindar, 2013); bilimsel süreç becerileri (Güngör, 2016) ile diğer becerilerdir (Balım, İnal ve Evrekli, 2008; Evrekli ve Balım, 2010; Tekin, İnci, Aslan ve Yağız, 2013). İlgili tema altında bu araştırmaların fazla oluşu, fen eğitiminde kavram öğretimi üzerinde etkili olabilecek yöntem ve teknik arayışından kaynaklanabilir. Bunun yanı sıra örnek etkinlik tasarımları ile kavram öğretim teknikleri hakkında öğretmen ve öğrenci görüşlerine yer veren araştırmaların sınırlı olduğu görülmüştür (Aydın ve Balım, 2007; Aydın ve Özyürek, 2014; Ecevit ve Özdemir Şimşek; 2017; İnel, Balım ve Evrekli, 2009; Yurtyapan ve diğ., 2017). Araştırmalarda genellikle bir ya da birden fazla kavram öğretim tekniği seçilmiş ve bu tekniğin etkililiği incelenmiştir (Eroğlu, 2010). Tüm öğretim tekniklerini içerecek örnek etkinliklerin tasarlanması, belli bir uzmanlık bilgisi ve çaba gerektirmektedir. Dolayısıyla tasarım temelli araştırmaların sayıca az oluşu bu durumla ilgili olabilir. Bu tema altında ayrıca kavram yanılgıları konusunda yürütülen araştırmaların da oldukça fazla oluşu dikkat çekicidir. Alkış Küçükaydın (2019a), fen eğitiminde var olan kavram yanılgılarının tespiti ve giderilmesi ile bu esnada kullanılacak yaklaşımların sınıf ortamında eğitsel açıdan büyük bir fırsat olacağını bildirmiştir. Kavram yanılgılarının belirlenmesi ve tespiti, dolayısıyla bu süreçte kavramsal değişimin sağlanması, fen eğitiminde oldukça önemli bir durumdur. Bu nedenle ilgili yöntem ve tekniklere başvurulması olağan bir durumdur (Yağbasan ve Gülçiçek, 2003). Bu çalışmada da kavram yanılgısı konusunda fazlaca sayıda araştırmaya ulaşılmış olması fen eğitiminde bu konunun hâlâ güncelliğini kaybetmediğini göstermektedir.

İncelenen konu temasına bakıldığında, aralarında çok büyük fark olmamakla birlikte biyoloji konularının, fizik ve kimya konularına göre daha fazla incelendiği görülmüştür. Bu durum, örneklem olarak ortaokul öğrencilerinin yoğunluğu dikkate alınarak, günlük yaşamla daha fazla ilişkilendirilen bir alan olmasından kaynaklanabilir. Bu dönem çocuklarının ergenlikle beraber insan yapısına ilgi ve merak duyması, araştırmacılar tarafından göz önüne alınmış ve araştırmalarını bu konuda yoğunlaştırmış olabilirler. Bununla beraber çevre konusunda sadece 2 çalışmaya rastlanmıştır (Aydın ve Özyürek, 2014; Erdoğan ve Cerrah Özsevgeç, 2012). Alanyazında çevre konusuyla ilgili pek çok kavram bulunmasına rağmen az sayıda araştırma yapılması, bu alanda bir araştırma boşluğu olduğuna işaret etmektedir. Dolayısıyla özellikle ilkokul düzeyinde çevre kavramlarını içerecek yeni araştırmalara ihtiyaç duyulduğunu söylemek mümkündür.

İncelenen araştırmaların çok büyük bir bölümünün nicel araştırma yöntemlerinden deneysel desenle yürütüldüğü görülmüştür. Nitel araştırma desenlerinin ise çok fazla tercih edilmediği, 4 nitel araştırmada tercih edilen desenin ise açıkça belirtilmediği tespitler arasındadır (Çıldır ve Şen, 2006; İnel ve diğ., 2009; Uzoğlu, Yıldız, Demir ve Büyükkasap, 2013; Ünlü, Kandil İngeç ve Taşar, 2006). Deneysel araştırmaların fazlaca tercih edilmesinin nedeni, araştırmalarda kavram öğretim yöntem/tekniklerinin sürekli bir biçimde etkililiğinin tespit edilmesinden kaynaklı olabilir. Ancak bu durum araştırmacılar için yeni çalışma kapılarını da aralamaktadır. Çünkü etkililik çalışmalarında kimi zaman birden fazla yöntem/teknik araştırılmış ve öğretim basamağına göre bir teknik diğerinden daha etkili bulunmuştur (Tarım, 2017). Bu durum, ilgili alanyazında bu araştırmaları bir araya getirerek etkililik durumlarını incelemeyi gerekli kılan meta analizlere ihtiyaç duyulduğunu göstermektedir. Fakat ilgili alanyazında konuyla ilgili meta analiz çalışmaları oldukça sınırlı sayıdadır (Alkış Küçükaydın, 2019b; Yokuş ve Ayçiçek, 2019). Bu nedenle farklı öğretim basamaklarında ve farklı yöntem/tekniklere odaklanarak yapılacak yeni meta analizlerle kavram öğretimi konusuna güncel bakış açılarının kazandırılmasına katkı sağlanabilir. Bununla beraber karma yöntemlerin sadece doktora tezlerinde kullanılması (Güngör, 2016; Turan Oluk, 2016), bu alanda karma yöntemlerle yürütülecek çalışmalara da ihtiyaç olduğunu göstermektedir.

İncelenen araştırmaların büyük bir bölümünün örneklem olarak ortaokul öğrencilerini seçtiği, ikinci sırada da öğretmen adaylarının yer aldığı görülmüştür. Örneklemlerin büyük bir çoğunluğunun ortaokul öğrencilerinden oluşmasının nedeni, değiştirilen ya da revize edilen fen bilimleri öğretim programları sonrası (MEB, 2005;2013; 2018) öğrencilerdeki kavram imajlarının incelenmesi ihtiyacından kaynaklı olabilir. Bu durum, takip çalışmalarıyla devam edip lise öğrencileriyle yürütülmüş ve araştırmalara da yansımış olabilir. İkinci ihtimal, öğretmen eğitimcilerinin öğretmen adaylarına ulaşmalarının kolaylığı düşünülebilir. Fakat bu sonuçlar, sahadaki öğretmenlerle çalışmanın çok tercih edilmediğini göstermektedir. Oysaki kavramların öğretimi konusunda kullanılacak öğretim yöntem/tekniği seçecek ve belli bir yaklaşımı benimseyecek olan öğretmenlerle daha fazla araştırma yürütülmesine ihtiyaç bulunmaktadır. Bu çalışmada ayrıca ilkokul düzeyinde sadece 2 araştırmaya rastlanılmıştır (Utku, Karakuyu, Marulcu ve Doğan, 2011; Uyanık ve Dindar, 2016). Oysaki kavramların oluşumu 
ve şekillenmeye başlaması küçük yaşlardan itibaren gerçekleşmektedir (Riche, 2000). Dolayısıyla ilkokul çağlarından itibaren farklı kavram öğretim yöntem/tekniklerine (Einsiedler ve Treinies, 1997) ve bu konudaki araştırmalara ihtiyaç duyulmaktadır.

Çalışmanın veri toplama araçları teması incelendiğinde en fazla 2-3 aşamalı başarı ya da kavram testlerinin kullanıldığ 1 görülmektedir. Bu durumun nedeni, araştırmaların kavram yanılgısı üzerine yoğunlaşması ile yanılgıları tespit ve giderme aşamasında 2 ya da 3 aşamalı testlerin tercih edilmesi olabilir. Araştırmalarda tutum ölçeklerinin de sıklıkla tercih edildiği görülmüştür. Fen eğitiminde genellikle bir ya da birden fazla kavram öğretim yöntemi kullanılarak, deneysel araştırmalar yürütülmüş ve bu yöntemin, öğrencilerin fen bilgisine yönelik tutumları üzerindeki etkileri araştırılmıştır. Bu durum kavram öğretiminde kullanılan yöntem ve tekniklerin (kavram haritası, kavram karikatürü, kavram çarkı diyagramı, analoji, TGA) aynı zamanda veri toplama aracı olarak kullanılmasını sağlamıştır. Araştırmaların çoğunlukla deneysel desende yürütülmesine bağlı olarak değişkenler çeşitlilik göstermiş; veri toplama aracı olarak motivasyon ölçekleri (İnel ve Balım, 2011; Özdemir ve Dindar, 2013), beceri ölçekleri (Balım ve dĭğ., 2008; Evrekli ve Balım, 2010; Güngör, 2016) ile mantıksal düşünme yeteneği testleri (Arslan Karakethüdaoğlu, 2010; Karakuyu ve Tüysüz, 2011; Uyanık ve Dindar, 2016) kullanılmıştır. Bununla beraber nitel araştırma yöntemlerinin az tercih edilişi, nitel araştırmalara özgü veri toplama araçlarının da sayıca az kullanılmasına sebep olmuştur. Bu durum, nitel araştırmalarla daha derinlemesine incelemelere ihtiyaç duyulduğunu işaret etmektedir. Çünkü araştırmalarda öğrencilerin ya da öğretmenlerin kavram yapılarının incelenmediği, kavram oluşum süreçlerinin dikkate alınmadığı ve esasında var olan kavram imajlarının ne olduğunun sorgulanmadığı söylenebilir. Bu incelemelerin, nitel veri toplama araçları kullanılarak derinlemesine ve ayrıntılı bir şekilde yapılması gerektiği anlaşılmaktadır.

Veri analiz yöntemi temasına bakıldığında, ilgili araştırmaların deneysel desenle yürütülmesine bağlı olarak sayıca t-testi kullanımının fazla olduğu görülmektedir. Aynı durum araştırmaların veri setinin non-parametrik istatistik tekniklerine uygun olmasına bağlı olarak Mann Whitney U-testi ve Wilcoxon işaretli sıralar testinin de fazla kullanımına yol açmıştır. Nitel yöntemlerin fazla tercih edilmeyişi, nitel verilere özgü analiz yöntemlerinin de az kullanılmasına neden olmuş olabilir. Bu durum ayrıca araştırmaların genelleme kaygısı taşıdığını da gösterebilir. Öğrencilerin ya da öğretmenlerin kavramlara ilişkin bilgi yapıları, imajları ve kavram gelişsimlerinin derinlemesine incelenmesi; uzun süreli ve küçük örneklemlerle, görüşme, gözlem, alan notları ve günlüklerle ya da alternatif puanlama anahtarları ile yapılabilir.

Sonuç teması incelendiğinde, kavram yanılgılarının belirlenmesi ve giderilmesi için yapılan müdahalelerin etkili olduğu görülmüştür. Deneysel desenlerle yürütülen bu araştırmalarda, deney grubunda kavram yanılgılarının tespiti ve giderilmesi için ilgili alanyazında önerilen yöntemler kullanılırken, kontrol grubunda geleneksel öğretim yöntemleri tercih edilmiştir. Elde edilen sonuçların tamamının olumlu oluşu, bu yöntemlerin kavram yanılgısı konusunda kullanılabilecek yararlı yöntemler olduklarını göstermektedir. Bununla beraber kavram haritası ile diğer araçların güvenirlik ve etkililiği açısından karşılaştırıldığı araştırmalarda (Aydın ve Özyürek, 2014; Çetinkaya ve Taş, 2011; Sarı, 2014) kavram haritasının daha etkili olduğu sonucuna ulaşılmıştır. Tarım'ın (2017) çalışmasında ise analoji ve kavramsal değişim metinlerinin etkisi karşılaştırılmış, analojilerin kavram yanılgılarını giderme konusunda daha etkili olduğu görülmüştür. Bu sonuçlar kavram yanılgılarının tespiti ve giderilmesinde ilgili yöntemlerin etkili olduğunu bildirmekte ancak karşılaştırmalı çalışmalara daha fazla önem verilmesini ve bu konudaki çalışmaların artırılması gerektiğine işaret etmektedir. Ayrıca bu yöntemlerin teknoloji ile entegre hâle getirilerek kullanılmasının, öğretimde daha etkili olacağı çıkarımında da bulunulabilir. Kullanılan kavram öğretim yöntem/tekniklerinin değişkenler üzerindeki etkileri incelendiğinde ise çoğunlukla olumlu etki ile karşılaşılmıştır. Ancak 12 araştırmanın sonucunda bu yöntem/tekniklerin hiçbir etkisinin olmadığı, 1 araştırmada ise olumsuz etki gösterdiği tespiti yapılmıştır. Evrekli ve arkadaşlarının (2012) araştırmasında kavram haritalarının uygulandığı grupta kavram öğrenme son test puanlarında düşüş görülmüştür. Herhangi bir etkinin olmadığ araştırmalardaki değişkenler sırasıyla tutum (Arslan Karakethüdaoğlu, 2010; Başer ve Çataloğlu, 2005; Demir, 2016; Doğan, 2016; Evrekli ve diğ., 2012; Kuşakçı Ekim, 2007; Özdemir ve Dindar, 2013; Tekin ve diğ., 2013; Yıldırım, 2018; akademik başarı (Balım ve diğ., 2008; Ceylan, 2008) ve beceridir (Evrekli ve Balım, 2010). Dolayısıyla kavram öğretim yöntem ve tekniklerinin genel anlamda kavram öğretiminde, kavram yanılgılarını tespit etme ve gidermede etkili olduğunu ancak duyuşsal davranışların değişimi konusunda çok başarılı olmadığg görülmektedir. Bu durum, duyuşsal davranışların, bilişsel davranışlara göre daha dirençli ya da daha uzun sürede değişmesinden kaynaklı olabilir. Dolayısıyla bu öğretim yöntem ve tekniklerinin teknoloji gibi başka bileşenlerle ya da farklı yöntemlerle birleştirilerek kullanılması sonucunda tutum üzerindeki etkileri boylamsal çalışmalarla araştırılabilir.

Çalışmada ayrıca öneri temasına yer verilmiştir. Bu temada öğretmenlere, alternatif kavram öğretimi yöntem ve tekniklerini sıklıkla kullanmaları (Evrekli ve Balım, 2010; Kurnaz, 2010; Özay Köse, 2014; Özyılmaz Akamca ve Hamurcu, 2009; Ulusoy, 2018); kavram öğretimlerini günlük yaşamla ilişsilendirmeleri (Harman, 2014); sadece fen bilimleri değil diğer derslerde de birden fazla yöntem işe koşularak öğrenci merkezli öğretim yapılması (Gölgeli ve Saraçoğlu, 2011) önerilmiştir. MEB'e yönelik öneriler ele alındığında genellikle öğretmenlere hizmet içi eğitimin verilmesi vurgusuna rastlanmıştır (Aydın ve Özyürek, 2014; Balım ve diğ., 2008; Erdoğan ve Cerrah 
Özsevgeç, 2012; Evrekli ve Balım, 2010; Özyılmaz Akamca ve Hamurcu, 2009; Uzoğlu ve diğ., 2013). Pek çok araştırmada özellikle teknoloji destekli kavram öğretim yöntem ve tekniklerinin öğretmenlere öğretilmesi için destek olunması gerektiği belirtilmiştir (Aydın ve Özyürek, 2014; Çetinkaya ve Taş, 2011; Evrekli ve diğ., 2012; Şendur, Toprak ve Pekmez, 2008). Sıklıkla vurgulanan bir diğer öneri ise ders kitaplarına kavram haritası, kavram karikatürü, TGA ya da analoji vb. içeren etkinlik örneklerinin daha fazla konulmasını sağlayarak hem öğretmen hem de öğrencilere rehberlik edilmesinin önünün açılması şeklinde olmuştur (Gölgeli ve Saraçoğlu, 2011; İnel ve diğ., 2009; Temelli ve Kurt, 2011; Uzoğlu ve diğ., 2013; Yavuz ve Çelik, 2013). 2 çalışmada ise (Artun ve diğ., 2019; Atasoy ve diğ., 2013) kavram öğretim yöntem ve tekniklerinin sınıf ortamında pratik biçimde kullanılması için öğretmenlere yönelik workshop ya da çalıştaylar düzenlenerek beceri gelişimlerine katkıda bulunulması önerilmiştir. Öğretmen eğitimcilerine yönelik özellikle ders esnasında teorinin yanında uygulamalı eğitimlere ağırlık verilmesi (Aydın ve Balım, 2007; Tekin ve diğ., 2013; Yıldırım, 2017); meslek hayatına atılmadan önce öğretmen adaylarının kavram yanılgılarının belirlenerek giderilmesi önerilerinde (Uyanık ve Dindar, 2016) bulunulmuştur. Araştırmacılara yönelik sunulan öneriler incelendiğinde ise özellikle deneysel çalışmalar sonrasında yürütülecek çalışmaların daha uzun soluklu olması (İnel ve Balım, 2011; Karakuyu ve Tüysüz, 2011; Temelli ve Kurt, 2011); kavram yanılgılarının yeniden ortaya çıkması ihtimaline karşı son testlerin sayısının artırılması (Temelli ve Kurt, 2011); birden fazla yöntem ve tekniğin etkililiğinin karşılaştırmalı incelemelerinin yapılması (Akyürek ve Afacan, 2013; Evrekli ve diğ., 2012) ve tutum, akademik başarı ya da beceri dışındaki diğer değişkenler üzerindeki etkilerinin de incelenmesi (Çinici ve diğ., 2014) önerilmiştir. İlgili araştırmalarda sunulan öneriler incelendiğinde; tasarıma dayalı ya da ilgili yöntem ve tekniklerin kullanımı ile ilgili sınıf kültürünün nasıl oluşturulacağı ve bu yöntem/tekniklerin sürdürülebilirliği konusunda herhangi bir yaklaşıma yer verilmediği görülmüştür. Bu tür öneriler, araştırmaların, amaçları ile doğru orantılı olarak, bağlamlarının dışında kalmış olabilir.

Çalışmada, yukarıda belirtilen parametrelere ek olarak, ele alınan araştırmalarda tercih edilen fen kavram öğretim yöntem ve teknikleri de incelemeye dâhil edilmiştir. Buna göre kavram öğretim yöntem ve teknikleri teması incelendiğinde, en fazla tercih edilen ve incelenen tekniğin kavram haritası olduğu görülmektedir. Bu durumun nedeni, kavram haritalarının en bilinen tekniklerden biri olması olabilir. Kavram haritaları, kavramsal ölçümler açısından geçerli bir mekanizma sunmakta olup geleneksel yöntemlere ek olarak alternatif bir araç olarak kullanılabilmektedir. Ayrıca kavram haritalarıyla kısa süreli öğretimsel müdahaleler sonucu gerçekleşen kavramsal değişimin ölçümü mümkündür (Wallace ve Mintzes, 1990). Kavram haritaları, bu özelliklerinden dolayı araştırmalarda sıklıkla kullanılmış olabilir. Bu çalışmada kavram haritalarından sonra en fazla kullanılan yöntemin kavram karikatürleri olduğu görülmüştür. Kavram karikatürleri biraz daha fazla zahmet ve farklı becerileri gerekli kılmaktadır. Çünkü hem yazılı hem de görsel bir formda hazırlanması, 3 ya da 5 kişilik öğrenci gruplarıyla karşılıklı diyaloglar içermesi ve sağlam bir kurgu gerektirmektedir (Ekici, Ekici ve Aydın, 2007). Bu nedenle kullanım açısından çok fayda getirecek fakat hazırlanma aşaması emek isteyen bir yöntemdir. Dolayısıyla kavram haritasına göre daha az kullanılma nedenlerinden birinin bu olduğu düşünülebilir. Kavramsal değişim metinleri ise ilgili çalışmalarda ele alınan bir diğer yöntemdir. Bu metinler bireylerin kavram yanılgılarını ele alarak, onların yanılgılarını gidermek ve ilgili yanılgıları hakkında memnuniyetsizlik yaratarak kavramsal değişimi teşvik eden stratejilere odaklanmak üzere tasarlanmıştır. Bunun için kişilere, hem anlaşılabilir hem de makul olan doğru bir açıklama sunulur. Bu açıklamalarla, öğrenciler doğru kavramlar konusunda bilgilendirilir (Özmen, 2007). Dolayısıyla bu yöntem, kavram yanılgılarının belirlenmesi ya da giderilmesini amaçlamayan diğer araştırmalarda kullanılmamıştır. Bu yöntemlerden başka, TGA, analoji, anlam çözümleme tablosu, zihin haritası ve kavram çarkı diyagramları kullanılmıştır. Ayrıca ilgili çalışmalarda çok fazla tercih edilmediği görülen çoklu yazma etkinlikleri (Akçay ve diğ., 2014); modelleme (Aydın ve Balım, 2007); deney (Bayram ve Ersoy, 2014); 6sigma (Sontay ve Karamustafaoğlu, 2018) ve hikâyelendirme (Doğan, 2016) tekniklerine de rastlanmıştır. Diğer yandan, 2007 yllından sonraki araştırmalarda ağırlıklı olarak bilgisayar ve web destekli kavram öğretim tekniklerine yer verildiği görülmüştür (Aydın ve Özyürek, 2014; Çetinkaya ve Taş, 2011; Evrekli ve diğ., 2012; Sarı, 2014). Ancak teknoloji destekli öğretimin desteklendiği ve yaygınlaştırılmaya çalışıldığı günümüz dünyasında popülerliğini kaybetmeyen kavram haritası ya da karikatürlerin de bu içerikle hazırlanması mümkündür. Ayrıca çok tercih edilen bu yöntemler dışında alanyazında çok az rastlanılan kavram analizi (Cansüngü Koray ve Bal, 2002); kavram ağları (Hewson ve Hewson, 1983); tanılayıcı dallanmış ağaç (Kocaarslan, 2012) ve birleştirici benzetme yöntemleri (Yılmaz, 2007) teknoloji ile bütünleştirilerek, birer kavram öğretim tekniği olarak incelenebilir.

$\mathrm{Bu}$ çalışmanın sonuçlarına dayalı olarak aşağıdaki öneriler sunulmuştur:

1. Bilindiği üzere 2018 yılında fen bilimleri dersi öğretim programı yenilenmiş ve STEM entegre bir program uygulamasına geçilmiştir. Bununla beraber fen bilimlerinde kavram öğretimi konusunun her zaman önemli olduğu ve bu önemini korumaya devam edeceği öngörülmektedir. Dolayısıyla kavram öğretiminin STEM uygulamaları ile bütünleşeceği yeni araştırmalar yürütülebilir. 
2. Kavram öğretimi konusunda tasarım temelli çalışmalara ihtiyaç duyulmaktadır. Tasarım temelli çalışmaların öğretimin ilk yıllarında yapılması ise bilimin sevdirilmesi açısından önemlidir. Bu nedenle ilkokul yıllarından itibaren kavram öğretimi konulu tasarım çalışmaları yapılabilir.

3. Bu çalışmada özellikle karma yöntemlerle yürütülen çalışmaların sadece doktora tezleriyle sınırlı olduğu görülmüştür. Buradan yola çıkarak öğretmen ve öğrencilerde kavram oluşum ve değişim sürecinin yöntemsel çeşitlilik sağlanarak derinlemesine araştırılması önerilebilir. Ayrıca kavram öğretim yöntem ve tekniklerinin etkililik düzeylerinin incelenmesi için meta analiz çalışmaları yapılabilir.

4. Teknoloji kullanımının yaygınlaştığı günümüz dünyasında fen eğitiminde kavram öğretiminin de teknolojiyle bütünleşmeye ihtiyacı vardır. Bu nedenle bilgisayar ya da web tabanlı kavram haritaları, kavram karikatürleri, zihin haritaları, analoji vb. tekniklerin bilişüstü becerilere ya da 21 . yüzyıl becerilerine olan etkileri incelenebilir.

Etik Kurul İzin Bilgisi: Bu araştırma, alanyazında erişsime açık yayınlar üzerinde yürütüldüğünden etik kurul izni alınmamıştır. 


\section{Kaynakça/References}

Akçay, H., Özyurt, B. B. ve Akçay, B. B. (2014). Çoklu yazma etkinliklerinin fen ve teknoloji dersi öğretiminde kullanılmasının öğrenci başarısı ve kavram öğrenmeye etkisi. Bayburt Eğitim Fakültesi Dergisi, 9(2), 15-31.

Alkış Küçükaydın, M. (2019a). Sınıf öğretmenlerinin fen kavram yanılgılarına ilişkin zihinsel modelleri. Eğitim ve Insani Bilimler Dergisi: Teori ve Uygulama, 10(19), 131-152.

Alkış Küçükaydın, M. (2019b). Fen eğitiminde kullanılan kavram karikatürlerinin akademik başarıya etkisi: Metaanaliz çalışması. İп̈nü Üniversitesi Eğitim Fakültesi Dergisi, 20(1), 220-233. doi:10.17679/inuefd.434352

Aydoğan, Ş. ve Köksal, E. A. (2017). İlköğretim fen eğitiminde kavram yanılgıları konusunda yapıllan çalışmaların içerik analizi. Eğitimde Kuram ve Uygulama, 13(2), 232-260.

Bağ, H. ve Çalık, M. (2017). İlköğretim düzeyinde yapılan argümantasyon çalışmalarına yönelik tematik içerik analizi. Eğitim ve Bilim, 42(190), 281-303. doi:10.15390/EB.2017.6845

Bağ, H. ve Çalık, M. (2018). İlkokul 4. sınıf düzeyindeki fen eğitimi araştırmalarının tematik içerik analizi. İlköğretim Online, 17(3), 1353-1377. doi:10.17051/ilkonline.2018.466357

Bearman, M., Smith, C. D., Carbone , A., Slade, S., Baik, C., Hughes-Warrington, M., \& Neumann, D. L. (2012) Systematic review methodology in higher education, Higher Education Research \& Development, 31(5), 625-640. doi:10.1080/07294360.2012.702735

Butler, J., Mooney Simmie, G., \& O’Grady, A. (2015). An investigation into the prevalence of ecological misconceptions in upper secondary students and implications for pre-service teacher education. European Journal of Teacher Education, 38(3), 300-319. doi:10.1080/02619768.2014.943394

Byrne, M. S., \& Johnstone, A. H. (1988). How to make science relevant. School Science Review, 70(251), 43-46.

Cansüngü Koray, Ö. ve Bal, Ş. (2002). İlköğretim 5. ve 6. sınıf öğrencilerinin ışık ve 1şığın hızı ile ilgili yanlış kavramları ve bu kavramları oluşturma şekilleri. Gazi Üniversitesi Gazi Eğitim Fakültesi Dergisi, 22(1),111.

Coştu, B., Karataş, F. Ö. ve Ayas, A. (2003). Kavram öğretiminde çalışma yapraklarının kullanılması. Pamukkale Üniversitesi Ë̆itim Fakültesi Dergisi, 14(14), 33-48.

Çam, O. ve Bilge, A. (2013). Türkiye'de ruhsal hastalığa/hastaya yönelik inanç, tutum ve damgalama süreci: Sistematik derleme. Psikiyatri Hemşireliği Dergisi, 4(2), 91-101. doi:10.5505/phd.2013.92300

Çaycı, B. (2007). Kavram değiştirme metinlerinin kavram öğrenimi üzerindeki etkisinin incelenmesi. Gazi Üniversitesi Gazi Eğitim Fakültesi Dergisi, 27(1), 87-102.

Ecevit, T. ve Özdemir Şimşek, P. (2017). Öğretmenlerin fen kavram öğretimleri, kavram yanılgılarını saptama ve giderme çalışmalarının değerlendirilmesi. İlköğretim Online, 16(1), 129-150. doi:10.17051/io.2017.47449

Eggen, P., \& Kauchak, D. (2004). Educational psychology: Windows on classrooms (6th ed.). Upper Saddle River. NJ: Prentice-Hall.

Einsiedler, W., \& Treinies, G. (1997). Effects of teaching methods, class effects, and patterns of cognitive teacherpupil interactions in an experimental study in primary school classes. School Effectiveness and School Improvement, 8(3), 327-353.

Ekici, F., Ekici, E., \& Aydin, F. (2007). Utility of concept cartoons in diagnosing and overcoming misconceptions related to photosynthesis. International Journal of Environmental and Science Education, 2(4), 111-124.

Evrekli, E., İnel, D. ve Balım, A. G. (2012). Kavram ve zihin haritası kullanımının öğrencilerin kavramları anlama düzeyleri ile fen ve teknolojiye yönelik tutumları üzerindeki etkileri. Abant İzzet Baysal Üniversitesi Eğitim Fakültesi Dergisi, 12(1), 229-250.

Frailich, M., Kesner, M., \& Hofstein, A. (2007). The influence of web-based chemistry learning on students' perceptions, attitudes, and achievements. Research in Science \& Technological Education, 25(2), 179-197.

Gökdemir, F., \& Dolgun, G. (2020). Writing material \& method section in qualitative, quantitative, systematic review, meta-analysis, and meta-synthesis studies. Archives of Health Science and Research, 7(2), 189-195.

Gül, Ş. ve Sözbilir, M. (2015). Fen ve matematik eğitimi alanında gerçekleştirilen ölçek geliştirme araştırmalarına yönelik tematik içerik analizi. Eğitim ve Bilim, 40(178), 85-102. doi:10.15390/EB.2015.4070 
Gülçiçek, Ç. ve Güneş, B. (2004). Fen öğretiminde kavramların somutlaştırılması: Modelleme stratejisi, bilgisayar simülasyonları ve analojiler. Ĕgitim ve Bilim, 29(134), 36-48.

Güneş, T., Şener Dilek, N. , Demir, E. S., Hoplan, M. ve Çelikoğlu, M. (2010, Kasım). Öğretmenlerin kavram öğretimi, kavram yanılgılarını saptama ve giderme çalışmaları üzerine nitel bir araştırma. International Conference on New Trends in Education and Their Implications, Antalya.

Hand, B., \& Treagust, D. F. (1991). Student achievement and science curriculum development using a constructive framework. School Science and Mathematics, 91(4), 172-176.

Häussler, P., \& Hoffman, L. (2000). A curricular frame for physics education: Development comparison with students' interest, and impact on students' achievement and self-concept. Science Education, 84(6), 689-705.

Herdem, K. ve Ünal, İ. (2018). STEM eğitimi üzerine yapılan çalışmaların analizi: Bir meta-sentez çalışması. Marmara Üniversitesi Atatürk Eğitim Fakültesi Eğitim Bilimleri Dergisi, 48(48),145-163. doi:10.15285/maruaebd.381417

Hewson, M. G., \& Hewson, P. W. (1983). Effect of instruction using students' prior knowledge and conceptual change strategies on science learning. Journal of Research in Science Teaching, 20(8), 731-743.

Hong, S. Y., \& Diamond, K. E. (2012). Two approaches to teaching young children science concepts, vocabulary, and scientific problem-solving skills. Early Childhood Research Quarterly,27(2), 295-305. doi:10.1016/j.ecresq.2011.09.006

İdin, Ş. ve Kaptan, F. (2017). İlköğretim fen eğitiminde yenilenen öğretim programlarına göre hazırlanan doktora tezlerinin incelenmesi üzerine bir çalışma. Eskişehir Osmangazi Üniversitesi Türk Dünyası Uygulama ve Araştırma Merkezi Ĕ̆itim Dergisi, 2(1), 29-43.

İnel, D., Balım, A. G. ve Evrekli, E. (2009). Fen ve teknoloji öğretiminde kavram karikatürü kullanımına ilişkin öğrenci görüşleri. Necatibey Eğitim Fakültesi Elektronik Fen ve Matematik Eğitimi Dergisi, 3(1), 1-16.

Kaltakçı Gürel, D., Eryilmaz, A., \& McDermott, L. C. (2015). A review and comparison of diagnostic instruments to identify students' misconceptions in science. Eurasia Journal of Mathematics, Science and Technology Education, 11(5), 989-1008. doi:10.12973/eurasia.2015.1369a

Karaçam, Z. (2013). Sistematik derleme metodolojisi: Sistematik derleme hazırlamak için bir rehber. Dokuz Eylül Üniversitesi Hemşirelik Fakültesi Elektronik Dergisi, 6(1), 26-33.

Karataş, F. Ö., Köse, S. ve Coştu, B. (2003). Öğrenci yanılgılarını ve anlama düzeylerini belirlemede kullanılan iki aşamalı testler. Pamukkale Üniversitesi Ĕ̈itim Fakültesi Dergisi, 13(13), 54-69.

Kocaarslan, M. (2012). Tanılayıcı dallanmış ağaç tekniği ve ilköğretim 5. sınıf fen ve teknoloji dersi maddenin değişimi ve tanınması adlı ünitede kullanımı. Mustafa Kemal Üniversitesi Sosyal Bilimler Enstitüsü Dergisi, 9(18), 269-279.

Martin, D. J. (2009). Elementary science methods: A constructivist approach. New York: Delmar Publishers.

Mead, G. H. (1909). Teaching of science in college. Science, 24, 390-397.

Miles, M. B., \& Huberman, A. M. (1994). Qualitative data analysis: An expanded source book. Thousand Oaks, CA: Sage.

Milli Eğitim Bakanlığı [MEB]. (2005). İlköğretim fen ve teknoloji dersi (6., 7. ve 8. sinıflar) öğretim programı. Ankara: MEB Yayınevi.

Milli Eğitim Bakanlığı [MEB]. (2013). İlköğretim kurumları (ilkokullar ve ortaokullar) fen bilimleri dersi (3., 4., 5., 6., 7. ve 8. sinıflar) öğretim programı. Ankara: MEB Yayınevi.

Milli Eğitim Bakanlığı [MEB]. (2018). Fen bilimleri dersi ögretim programı (İlkokul ve ortaokul 3, 4, 5, 6, 7 ve 8. sinfflar). http://ttkb.meb.gov.tr/ adresinden elde edildi.

Organisation for Economic Co-operation and Development [OECD]. (2019). PISA 2018 results (Volume I): What students know and can do. Paris: OECD Publishing.

Olson, J. K. (2008). Methods \& Strategies: Concept-focused teaching. Science and Children, 46(4), 45-49.

Ormrod, J. E. (2006). Educational psychology: Developing learners (5th ed). Pearson Prentice Hall.

Osborne, R. J., \& Wittrock, M. C. (1983). Learning science: A generative process. Science Education, 67, 489 508. 
Özatlı, N. S., \& Bahar, M. (2010). Öğrencilerin boşaltım sistemi konusundaki bilişsel yapılarının yeni teknikler ile ortaya konması. Abant İzzet Baysal Üniversitesi Ĕ̈itim Fakültesi Dergisi, 10(2), 9-26.

Özmen, H. (2007). The effectiveness of conceptual change texts in remediating high school students' alternative conceptions concerning chemical equilibrium. Asia Pacific Education Review, 8(3), 413-425.

Riche, R. D. (2000). Strategies for assisting students overcome their misconceptions in high school physics. Retrieved from http://www.bishops.ntc.nf.ca/rriche/ed6390/paper.html

Sandelowski, M. (1998). The call to experts in qualitative research. Research in Nursing \& Health, 21(5), 467471.

Thompson, F., \& Logue, S. (2006). An exploration of common student misconceptions in science. International Education Journal, 7(4), 553-559.

Türkmen, H. ve Ünver, E. (2018). Fen eğitiminde hikayelendirme tekniği. Journal of European Education, 2(1), 9-13.

Wallace, J. D., \& Mintzes, J. J. (1990). The concept map as a research tool: Exploring conceptual change in biology. Journal of Research in Science Teaching, 27(10), 1033-1052.

Wassink, F. K. ve Sadi, Ö. (2016). Türkiye'de fen bilimleri eğitimi yönelimleri: 2005 ile 2014 yılları arası bir içerik analizi. İlköğretim Online, 15(2), 594-614.

Yağbasan, R. ve Gülçiçek, A. G. Ç. (2003). Fen öğretiminde kavram yanılgılarının karakteristiklerinin tanımlanması. Pamukkale Üniversitesi Eğitim Fakültesi Dergisi, 13(13), 102-120.

Yıldırım, M., Çalık, M. ve Özmen, H. (2016). A meta-synthesis of Turkish studies in science process skills. International Journal of Environmental and Science Education, 11(14), 6518-6539.

Yllmaz, S. (2007). Finding anchoring analogies to help students' misconceptions in physics. (Unpublished dissertation). Middle East Technical University, Ankara.

Yokuş, G. ve Ayçiçek, B. (2019). Kavram karikatürlerinin fen eğitimi dersi akademik başarısı üzerindeki etkisini belirlemeye yönelik bir meta-analiz çalışması. Pamukkale Üniversitesi Eğitim Fakültesi Dergisi,1-23. doi:10.9779/pauefd.592287

Yurtyapan, E., Kandemir, N. ve Kandemir, Ş. (2017). Kavram karikatürü destekli fen öğretimi hakkında öğretmen adaylarının görüşleri. Ege Ĕgitim Dergisi, 18(2), 738-773. doi:10.12984/egeefd.279846 


\section{Ek A}

\section{Çalışmada İncelenen Araştırmaların Listesi}

Akbal, E. (2009). Ortaöğretim kimya ĕgitiminde mol konusunun öğretiminde kavramsal değişim metinlerinin başarıya etkisi. (Yayımlanmamış yüksek lisans tezi). Marmara Üniversitesi, İstanbul.

Akçay, H., Özyurt, B. B. ve Akçay, B. B. (2014). Çoklu yazma etkinliklerinin fen ve teknoloji dersi öğretiminde kullanılmasının öğrenci başarısı ve kavram öğrenmeye etkisi. Bayburt Ĕgitim Fakültesi Dergisi, 9(2), 15-31.

Aksoy, M. (2010).Ortaöğretim kimya dersindeki çözünürlük konusunun kavram haritaları ile öğretilmesinin ögrencilerin başarı ve tutumlarına etkisi. (Yayımlanmamış yüksek lisans tezi). Selçuk Üniversitesi, Konya.

Akyürek, E. ve Afacan, Ö. (2013). İlköğretim 8. sınıf öğrencilerinin “hücre bölünmesi ve kalıtım” ünitesindeki kavram yanılgılarının tespiti ve analoji ile kavramsal değişim metinleri kullanılarak giderilmesi. Ahi Evran Üniversitesi Kırşehir Eğitim Fakültesi Dergisi, 14(1), 175-193.

Arslan Karakethüdaoğlu, N. A. (2010). Kavramsal değişim yaklaşımına dayalı öğretimin kimyasal denge kavramlarını anlamaya ve tutuma etkisi. (Yayımlanmamış yüksek lisans tezi). Zonguldak Karaelmas Üniversitesi, Zonguldak.

Artun, H., Gülseven, E. ve Temur, A. (2019). Beşinci sınıf öğrencilerinin biyoçeşitlilik konusunu anlamaları üzerine kavram karikatürlerinin etkisi. Bolu Abant İzzet Baysal Üniversitesi Égitim Fakültesi Dergisi, 19(3), 721-731. doi:10.17240/aibuefd.2019.19.49440-486576

Atasoy, Ş., Tekbıyık, A. ve Gülay, A. (2013). Beşinci sınıf öğrencilerinin ses kavramını anlamaları üzerine kavram karikatürlerinin etkisi. Türk Fen Eğitimi Dergisi, 10(1), 176-196.

Aydın, G. ve Balım, A. G. (2007). Fen ve teknoloji öğretiminde kullanılan kavramsal değişim stratejilerine dayalı örnek etkinlikler. Dokuz Eylül Üniversitesi Buca Eğitim Fakültesi Dergisi, (22), 54-66.

Aydın, G. ve Özyürek, C. (2014). Işık kirliliği konusunun bilgisayar destekli kavram karikatürleriyle öğretimi. Araştırma Temelli Etkinlik Dergisi, 4(2), 54-71.

Aykutlu, I. ve Şen, A. İ. (2011). Lise öğrencilerinin elektrik akımı konusundaki kavram yanılgılarının belirlenmesinde ve giderilmesinde analojilerin kullanılması. Necatibey Ĕ̈itim Fakültesi Elektronik Fen ve Matematik Ĕ̈itimi Dergisi, 5(2), 221-250.

Balım, A. G.,İnel, D. ve Evrekli, E. (2008). Fen öğretiminde kavram karikatürü kullanımının öğrencilerin akademik başarılarına ve sorgulayıcı öğrenme becerileri algılarına etkisi. İlköğretim Online, 7(1),188-202.

Başer, M. ve Çataloğlu, E. (2005). Kavram değişimi yöntemine dayalı öğretimin öğrencilerin 1s1 ve sicaklık konusundaki "yanlış kavramlar"ının giderilmesindeki etkisi. Hacettepe Üniversitesi Eğitim Fakültesi Dergisi, 29(29), 43-52.

Bayram, H. ve Ersoy, N. (2014). 7. sınıf öğrencilerinin maddelerin sınıflandırılması ve değişimi konusundaki kavram yanılgılarının deney ve kavram haritası yöntemi ile giderilmesi. Marmara Üniversitesi Atatürk Ĕ̈itim Fakültesi Eğitim Bilimleri Dergisi, 40(40), 31-46.

Bilen, K. ve Köse, S. (2012). Kavram öğretiminde etkili bir strateji TGA (tahmin et- gözle- açıkla) bitkilerde madde taşınımı. Mehmet Akif Ersoy Üniversitesi Ĕ̈itim Fakültesi Dergisi, 1(24), 21-42.

Candan, A., Türkmen, L. ve Çardak, O. (2006). Kavram haritalamanın ilköğretim öğrencilerinin hareket ve kuvvet kavramlarını anlamalarına etkileri. Türk Fen Ĕ̈itimi Dergisi, 3(1), 66-75.

Ceylan, H. (2008). Illköğretim fen ve teknoloji dersinde altıncı sınıf öğrencilerine elektrik konusunun ögretiminde kavramsal değişim yaklaşımının öğrenci başarısına ve tutumuna etkisi. (Yayımlanmamış yüksek lisans tezi). Gazi Üniversitesi, Ankara.

Çakmak, M., Gürbüz, H. ve Kaplan, H. (2012). Dolaşım sistemimiz konusunda uygulanan kavram haritalarının öğrencilerin akademik başarısına etkisi. Adıyaman Üniversitesi Sosyal Bilimler Enstitüsü Dergisi, 10, 9-28.

Çayci, B. (2007). Kavram değiştirme metinlerinin kavram öğrenimi üzerindeki etkisinin incelenmesi. Gazi Üniversitesi Gazi Eğitim Fakültesi Dergisi, 27(1), 87-102.

Çetinkaya, M. ve Taş, E. (2011). Canlıların sınıflandırılması konusu için web destekli kavram haritaları ve anlam çözümleme tablolarının öğrenme üzerindeki etkisinin araştırılması. Dicle Üniversitesi Ziya Gökalp Ĕgitim Fakültesi Dergisi, (16), 180-195. 
Çıldır, I. ve Şen, A. İ. (2006). Lise öğrencilerinin elektrik akımı konusundaki kavram yanılgılarının kavram haritalarıyla belirlenmesi. Hacettepe Üniversitesi Ĕ̈itim Fakültesi Dergisi, 30(30), 92-101.

Çinici, A., Özden, M., Akgün, A., Herdem, K., Deniz, Ş. M. ve Karabiber, H. L. (2014). Kavram karikatürleriyle desteklenmiş argümantasyon temelli uygulamaların etkinliğinin incelenmesi. Adryaman Üniversitesi Sosyal Bilimler Enstitüsü Dergisi, (18), 571-596.

Demir, F. (2016). Osmoz-difüzyon kavramlarının öğretiminde kavram karikatürlerinin öğrenci başarısına etkisi. (Yayımlanmamış yüksek lisans tezi). Süleyman Demirel Üniversitesi, Isparta.

Doğan, L. (2016). Fen eğitiminde hikâyelendirme tekniği ile kavram öğretimine bir aksiyon örneği. (Yayımlanmamış yüksek lisans tezi). Erzincan Üniversitesi, Erzincan.

Ecevit, T. ve Özdemir Şimşek, P. (2017). Öğretmenlerin fen kavram öğretimleri, kavram yanılgılarını saptama ve giderme çalışmalarının değerlendirilmesi. Ilköğretim Online, 16(1), 129-150. Doi: 10.17051/10.2017.47449

Erdoğan, A. ve Cerrah Özsevgeç, L. C. (2012). Kavram karikatürlerinin öğrencilerin kavram yanılgılarının giderilmesi üzerindeki etkisi: Sera etkisi ve küresel ısınma örneği. Turkish Journal of Education, 1(2), 3850.

Eroğlu, M. G. (2010). Kavram haritası ve yapılandırılmış grid ile elde edilen puanların geçerlilik ve güvenirliliklerinin incelenmesi. (Yayımlanmamış yüksek lisans tezi). Hacettepe Üniversitesi, Ankara.

Evrekli, E. ve Balım, A. G. (2010). Fen ve teknoloji öğretiminde zihin haritası ve kavram karikatürü kullanımının öğrencilerin akademik başarılarına ve sorgulayıcı öğrenme becerileri algılarına etkisi. Batı Anadolu Eğitim Bilimleri Dergisi, 1(2), 76-98.

Evrekli, E., İnel, D. ve Balım, A. G. (2012). Kavram ve zihin haritası kullanımının öğrencilerin kavramları anlama düzeyleri ile fen ve teknolojiye yönelik tutumları üzerindeki etkileri. Abant İzzet Baysal Üniversitesi Eğitim Fakültesi Dergisi, 12(1) 229-250.

Gölgeli, D. ve Saraçoğlu, S. (2011). Fen ve teknoloji dersi “1şık ve ses” ünitesinin öğretiminde kavram karikatürlerinin kullanımının öğrencilerin akademik başarısına etkisi. Erciyes Üniversitesi Sosyal Bilimler Enstitüsü Dergisi, 1(31), 113-124.

Güngör, S. N. (2016). Fen bilgisi öğretmen adaylarına tahmin-gözlem-açıklama (TGA) yöntemiyle biyolojik konu ve kavramların ögretiminin başarı, kalıcılık ve bilimsel süreç becerilerine etkisi. (Yayımlanmamış doktora tezi). Uludağ Üniversitesi, Bursa.

Harman, G. (2014). Hücre zarından madde geçişi ile ilgili kavram yanılgılarının tahmin-gözlem-açılama yöntemiyle belirlenmesi. Türk Fen Eğitimi Dergisi, 11(4), 81-106.

İnel, D. ve Balım, A. G. (2011). Kavram karikatürleri destekli probleme dayalı öğrenme yönteminin ilköğretim 6. sınıf öğrencilerinin fen öğrenmeye yönelik motivasyonlarına etkisi. Uşak Üniversitesi Sosyal Bilimler Dergisi, 4(1), 169-188.

İnel, D., Balım, A. G. ve Evrekli, E. (2009). Fen öğretiminde kavram karikatürü kullanımına ilişkin öğrenci görüşleri. Necatibey Eğitim Fakültesi Elektronik Fen ve Matematik Ĕ̈itimi Dergisi, 3(1), 1-16

Kandil İngeç, Ş. (2008). Kavram haritalarının değerlendirme aracı olarak fizik eğitiminde kullanılması. Hacettepe Üniversitesi Eğitim Fakültesi Dergisi, 35(35), 195-206.

Karakuyu, Y. ve Tüysüz, C. (2011). Elektrik konusunda kavram yanılgıları ve kavramsal değişim yaklaşımı. Gaziantep Üniversitesi Sosyal Bilimler Dergisi, 10(2), 825-838.

Kavak, S. (2009). Illköğretim 8.sınıffen ve teknoloji dersi maddenin halleri ve ısı ünitesinde kavram haritası tekniği kullanımının öğrencilerin başarısına, bilgilerin kalıcılı̆̆ına ve fene karşı tutumlarına etkisi. (Yayımlanmamış yüksek lisans tezi). Gazi Üniversitesi, Ankara.

Kurnaz, M. A. (2010). Kavram haritalarının öğretim sürecinde kullanılması: Bir aksiyon araştırması. Türk Eğitim Bilimleri Dergisi, 8(1), 175-199.

Kuşakçı Ekim, F. (2007). İlköğretim fen öğretiminde kavramsal karikatürlerin öğrencilerin kavram yanılgılarını gidermedeki etkisi. (Yayımlanmamış yüksek lisans tezi). Ankara Üniversitesi, Ankara.

Özay Köse, E. (2014). Hücre ve organellerin öğretiminde kavram haritalarının kullanılması. Uluslararası Türk Eğitim Bilimleri Dergisi, 116-121. 
Özdemir, A. M. ve Dindar, H. (2013). İlköğretim fen ve teknoloji dersinde kavramsal değişim yaklaşımının, öğrencilerin duyuşsal özellikleri üzerine etkisi. Gazi Üniversitesi Gazi Eğitim Fakültesi Dergisi, 33(1), 95107.

Özyılmaz Akamca, G. ve Hamurcu, H. (2009). Analojiler, kavram karikatürleri ve tahmin-gözlem-açıklama teknikleriyle desteklenmiş fen ve teknoloji eğitimi. Education Sciences, 4(4), 1186-1206.

Sarı, A. (2014). Kavram haritası ve bilgisayar destekli ögretimin 7. sinıf öğrencilerinin madde konusundaki kavram yanılgılarına etkisinin ontolojik açıdan incelenmesi. (Yayımlanmamış doktora tezi). Marmara Üniversitesi, İstanbul.

Sontay, G. ve Karamustafaoğlu, O. (2018). 6-sigma yöntemi ile 1sı ve sıcaklık konusunun öğretimi. MANAS Sosyal Araştırmalar Dergisi, 7(4), 31-48.

Şendur, G., Toprak, M. ve Pekmez, E. Ş. (2008). Buharlaşma ve kaynama konularındaki kavram yanılgılarının önlenmesinde analoji yönteminin etkisi. Ege Ĕ̈itim Dergisi, 9(2), 37-58.

Tarım, S. S. (2017). Asitler ve bazlar konusunda ögrencilerde var olan alternatif kavramların giderilmesinde kullanılan analoji ve kavramsal değişim metinlerinin kavramsal değişimi să̆lamada etkililiğinin karşılaştırılması. (Yayımlanmamış yüksek lisans tezi). Pamukkale Üniversitesi, Denizli.

Tekin, N., İnci, T., Aslan, O. ve Yağız, D. (2013). Fen ve teknoloji öğretmen adaylarının kavram haritalarına yönelik tutumları ve kavram haritası hazırlayabilme becerilerinin çeşitli değişkenler açısından incelenmesi. Ĕ̈itim Bilimleri Dergisi, 38,133-148.

Temelli, A. ve Kurt, M. (2011). Bitkilerde taşıma sistemi konusunun kavram haritalarıyla öğretilmesinin öğrencilerin akademik başarısına etkisi (Erzurum örneği). Necatibey Eğitim Fakültesi Elektronik Fen ve Matematik Ë̆itimi Dergisi, 5(2), 42-57.

Temelli, A., Arlı, E. E., Biber, B. ve Kurt, M. (2011). İnsanlarda solunum sistemi konusunun kavram haritalarıyla öğretilmesinin öğrencilerin akademik başarısına etkisi. Ĭgdır Üniversitesi Fen Bilimleri Enstitüsü Dergisi, 1(2), 61-66.

Turan Oluk, N. (2016). Kimya ĕgitiminde farklı kavram haritası oluşturma yöntemlerinin karşılaştırılması. (Yayımlanmamış doktora tezi). Gazi Üniversitesi, Ankara.

Ulusoy, G. (2018). Partenogenez ve partenokarpi kavramlarının biyoloji öğretmen adaylarına ögretiminde kavram haritasının öğrenmeye etkisi. (Yayımlanmamış yüksek lisans tezi). Necmettin Erbakan Üniversitesi, Konya.

Utku, N., Karakuyu, Y., Marulcu, İ. ve Doğan, M. (2011). İlköğretim fen ve teknoloji dersi fizik ünitelerinde kavram Haritalarının kullanımı. Mustafa Kemal Üniversitesi Sosyal Bilimler Enstitüsü Dergisi, 8(15), 323332.

Uyanık, G. ve Dindar, H. (2016). İlkokul 4. sınıf fen bilimleri dersinde kavramsal değişim metinlerinin kavram yanılgılarının giderilmesine etkisi. Gazi Üniversitesi Gazi Eğitim Fakültesi Dergisi, 36(2), 349-374.

Uzoğlu, M., Yıldız, A., Demir, Y. ve Büyükkasap, E. (2013). Fen bilgisi öğretmen adaylarının 1şıkla ilgili kavram yanılgılarının belirlenmesinde kavram karikatürlerinin ve açık uçlu soruların etkililiklerinin karşılaştırılması. Ahi Evran Üniversitesi Kırşehir Eğitim Fakültesi Dergisi, 14(1), 367-388.

Ünlü, P., Kandil İngeç, K. ve Taşar, M. F. (2006). Öğretmen adaylarının momentum ve impuls kavramlarına ilişkin bilgi yapılarının kavram haritaları yöntemi ile araştırılması. Eğitim ve Bilim, 31(139), 70-79.

Yavuz, S. ve Çelik, G. (2013). Sınıf öğretmenliği öğrencilerinin gazlar konusundaki kavram yanılgılarına tahmin et-gözle-açıkla tekniğinin etkisi. Karaelmas Ĕ̆itim Bilimleri Dergisi, 1(1), 1-20.

Yıldırım, B. (2018). Kavram karikatürleri ile zenginleştirilmiş kavramsal değişim metinlerinin sınıf öğretmeni adaylarının basit elektrik devreleri konusundaki kavramsal anlama ve tutumlarına etkisi. (Yayımlanmamış yüksek lisans tezi). Mehmet Akif Ersoy Üniversitesi, Burdur.

Yurtyapan, E., Kandemir, N. ve Kandemir, Ş. (2017). Kavram karikatürü destekli fen öğretimi hakkında öğretmen adaylarının görüşleri. Ege Ĕ̈itim Dergisi, 18(2), 738-773. 